\title{
Fluorescence Imaging of Extracellular Purinergic Receptor Sites and Putative Ecto-ATPase Sites on Isolated Cochlear Hair Cells
}

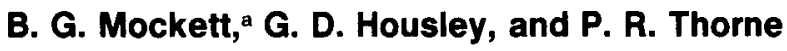 \\ Department of Physiology, School of Medicine, University of Auckland, Auckland, New Zealand
}

Fluorescence imaging of extracellular adenosine-5' -triphosphate (ATP) binding sites on inner and outer hair cells isolated from the guinea pig organ of Corti was achieved using the fluorescent analog of ATP, $2^{\prime}$-(or-3')-O-(trinitrophenyl)adenosine-5'-triphosphate (TNP-ATP; 30-75 $\mu \mathrm{M}$ ). This analog, which fluoresces on binding to these sites, was pressure applied by micropipette while hair cells were viewed by fluorescence microscopy. Fluorescence imaging revealed a widespread distribution of extracellular binding sites, including the stereocilia, cuticular plate, and the basolateral margins of the cells, but particularly in infracuticular and infranuclear regions. In support of extracellular binding, simultaneous electrophysiological recordings demonstrated that rapid washout of TNP-ATP-induced fluorescence was dependent upon cell integrity. Suramin, a nonselective $P_{2}$ purinoceptor antagonist, coapplied with TNP-ATP, reduced the fluorescence observed on the stereocilia and apical surface of the cuticular plate only. This implies that binding sites on the apical surface of hair cells are $P_{2}$ receptors, consistent with previous electrophysiological evidence for localization of $P_{2}$ receptors to the apical surface of cochlear hair cells (Housley et al., 1992). Binding of TNP-ATP to $P_{2}$ purinoceptors was confirmed by its antagonism of the inward current elicited by ATP $(10 \mu \mathrm{M})$ in voltage-clamped hair cells. Fluorescence from the basolateral margin was significantly quenched when TNP-ATP was applied in divalent cationfree solution. Because divalent cations are required for ATP. ase activity, this finding provides evidence for the presence of ecto-ATPases on the basolateral membrane of hair cells. The divalent cation-free condition had no significant effect on the ATP-gated $P_{2}$ purinoceptor conductance. We propose that there are two classes of ATP binding sites on cochlear hair cells: apically located $P_{2}$ purinoceptors gating nonselective cation channels and basolaterally located ecto-ATPases that may be involved in purine turnover.

\footnotetext{
Received Dec. 27, 1993; revised Apr. 29, 1994; accepted May 12, 1994.

This work was funded by the Health Research Council of New Zealand, the New Zealand Deafness Research Foundation, the New Zealand Lottery Grants Board, and the Auckland Medical Research Foundation. We thank Bayer Pharmaceuticals (Germany) for provision of the suramin. We also thank D. Greenwood for expert technical assistance; C. Eagleton, who contributed to the development of the imaging study; and N. Raybould, who assisted with the electrophysiology.

Correspondence should be addressed to Dr. G. D. Housley, Department of Physiology, School of Medicine, University of Auckland, Private Bag 92019, Auckland, New Zealand.

apresent address: Animal Production Unit, Invermay Agricultural Centre, Private Bag, Mosgiel, New Zealand.

Copyright (c) 1994 Society for Neuroscience $0270-6474 / 94 / 146992-16 \$ 05.00 / 0$
}

[Key words: purinoceptor imaging, cochlear hair cells, organ of Corti, extracellular ATP, $P_{2}$ purinergic receptors, 2 (or-3' )-O-(trinitrophenyl)adenosine-5' -triphosphate (TNP. ATP), suramin, divalent cations, ecto-ATPase, ectonucleotidases]

Since the first studies indicating that adenosine-5'-triphosphate (ATP) may act at extracellular sites to influence cell function (Drury and Szent-Györgyi, 1929; Burnstock, 1972), investigations have revealed physiological responses in a diverse range of cell and tissue types following exposure to extracellular ATP. These cell and tissue types include regions of the PNS (Bean and Friel, 1990; Evans et al., 1992; for reviews, see Burnstock, 1993a; Illes and Nörenberg, 1993) and CNS (Edwards et al., 1992; Burnstock, 1993a; Barnard et al., 1994); smooth, skeletal, and cardiac muscle (Bean and Friel, 1990; Satchell, 1990); endothelial cells (Gordon, 1990); and platelets, mast cells, lymphocytes, bladder, and vas deferens (see Gordon, 1986, for review). Physiological responses to extracellular ATP are wide ranging. They include contraction or relaxation of vascular smooth muscle, leading to alterations in vascular tone, relaxation of alimentary tract sphincters, release of relaxing factors by endothelial cells, platelet aggregation, histamine secretion by mast cells, and insulin secretion from the pancreas (for reviews, see Gordon, 1986; Burnstock, 1993a). There is also recent evidence that ATP may act as a cotransmitter (Burnstock, 1990; Westfall et al., 1990) or a principal neurotransmitter (Evans et al., 1992) in the PNS and CNS. Given such a diverse range of neurohumoral actions, it is becoming increasingly clear that extracellular ATP is an important regulatory purine for many different cell types.

In addition to the actions of ATP described above, there is now strong evidence for the presence of extracellular ATP purinoceptors on mammalian and avian cochlear sensory hair cclls. Studies have shown that extracellularly applied ATP can elicit changes in intracellular $\mathrm{Ca}^{2+}$ concentrations and transmembrane ion conductance in isolated hair cells (Ashmore and Ohmori, 1990; Nakagawa et al., 1990; Shigemoto and Ohmori, 1990; Dulon et al., 1991; Housley et al., 1992, 1993a,b; Ashmore et al., 1993). These effects are consistent with a $\mathrm{P}_{2}$ purinoceptor classification. Electrophysiological studies in this laboratory have shown that ATP receptors gate inwardly rectifying nonselective cation channels localized to the apical (endolymphatic) surface (Housley et al., 1992, 1993b). Collectively, studies of cochlear hair cells have established that extracellular ATP can modulate hair cell function, and indicate that ATP is functionally important in the sensory transduction of acoustic signals. 
To date, localization of ATP receptors on hair cells has been based on electrophysiological evidence. This, however, lacks the resolution to define the location of receptors precisely. More definitive localization could be obtained from a receptor marker that could be visualized microscopically. However, a significant obstacle to the visualization and localization of hair cell purinoceptors has been the lack of a reporter analog of ATP that can be visualized at the receptor site. The few ATP analogs currently available that have fluorophores or chromogens attached have been used for studies of DNA or intracellular enzyme systems. Examples of such analogs include the fluoronucleotides $1, N^{6}$-ethenoadenosine-5'-triphosphate and $2^{\prime}$-(or-3')- $O$-(trinitrophenyl)adenosine-5'-triphosphate (TNP-ATP). The former has been used in studies of enzymes requiring ATP as an energy source (phosphofructokinase) or adenylyl donor (adenylate kinase) (Secrist et al., 1972) and the latter for intracellular ATPase characterization (e.g., Watanabe and Inesi, 1982; Berman, 1986). Until the present study, none of these ATP analogs have been used to specifically study extracellular ATP receptors.

We report here the localization of extracellular ATP receptors on isolated cochlear hair cells by imaging the fluorescence emitted by the binding of the ATP analog, TNP-ATP. This is a novel application of this fluoronucleotide, which possesses the useful characteristic of exhibiting greatly enhanced fluorescence when bound to a receptor site, thus greatly reducing the problem of background fluorescence. We show in this study that TNP-ATP binds reversibly to extracellular ATP binding sites on cochlear hair cells and, in addition to the apically located purinoceptors, there is a further, previously undescribed class of ATP binding sites, which we attribute to ecto-ATPases, present on the basolateral membrane.

\section{Materials and Methods}

Animals and tissue preparation. Cochlear sensory hair cells were isolated from guinea pigs (250-800 gm; with approval from the University of Auckland Animal Ethics Committee) of either sex using a previously published procedure (Ashmore, 1987). Briefly, following decapitation or cervical dislocation, the temporal bone was removed and the cochlea within the auditory bulla exposed. The cochlea was then placed in an artificial perilymph-like external solution containing (in mmol/liter) $\mathrm{NaCl}$, $142 ; \mathrm{KCl}, 4 ; \mathrm{CaCl}_{2}, 1.5 ; \mathrm{MgCl}_{2}, 1 ; \mathrm{NaH}_{2} \mathrm{PO}_{4}, 2 ; \mathrm{Na}_{2} \mathrm{HPO}_{4}, 8$; and D-glucose, 3 . The pH was adjusted to 7.25 with $1 \mathrm{~N} \mathrm{NaOH}$ and the osmolarity of the solution was approximately $300 \mathrm{mOsm}$. The bony capsule of the cochlea was removed and the modiolus and attached organ of Corti dissected free. The latter was then microdissected from the modiolus under a stereoscopic microscope and collected in a $30 \mu \mathrm{l}$ droplet. A further $30 \mu \mathrm{l}$ of external solution containing $1 \mathrm{mg} / \mathrm{ml}$ trypsin (Sigma) was added and the tissue allowed to incubate for $10 \mathrm{~min}$. At the end of this period the cells were mechanically disassociated by trituration, placed in a $200 \mu$ l bath on the stage of a Nikon TMD inverted microscope, and viewed with Nomarski differential interference contrast optics. Following cell settling, the bath was superfused (at room temperature, $21-25^{\circ} \mathrm{C}$ ) at a flow rate of $400 \mu \mathrm{min}^{-1}$ (Gilson minipuls 2 pump).

Organ of Corti prepared in this manner yielded isolated IHC and OHC from basal through to apical regions that could then be identified and differentiated on the basis of cell morphology. Inner hair cells were identified as cells with a flask-shaped cell body and centrally located nucleus, whereas $\mathrm{OHC}$ had a cylindrical cell body shape and basally located nucleus.

Chemicals and test compound delivery. The following compounds were used in this study: ATP (1-10 $\mu \mathrm{M}$; Sigma), TNP-ATP $(30-75 \mu \mathrm{M}$; $\mathrm{T}-1003$, Molecular Probes, Eugene, OR), and suramin (250 $\mu \mathrm{M}$ to 1 mM; Bayer Pharmaceuticals, Germany). Preliminary experiments indicated that this concentration range of TNP-ATP was just on the threshold for producing fluorescence in the unbound state when using the maximum sensitivity of our imaging system, while the concentration of suramin used as a $P_{2}$ purinoceptor-selective blocker was determined empirically (see Results). All drugs were diluted in the external solution and were pressure applied to the cells via either fine single-barrel or double-barrel micropipettes (individual tip diameters of $2-5 \mu \mathrm{m}$ ) placed within 20-50 $\mu \mathrm{m}$ of the cell, or by rapid bath superfusion. Double-barrel micropipettes were fabricated in house from borosilicate glass capillaries (Clark Electromedical Instruments, England, GC120TF-10) by heat fusion and manual pulling of two capillaries followed by a second pull on a Narishige electrode puller (PB-7, Japan). This produced a single fused tip with two comparable lumens of the required diameters. A pneumatic injection driver based on a high-velocity three-way solenoid valve (Mac Valve 1116A551JD, Mac Valve Pacific Ltd., New Zealand) was used to apply pressure to the drug pipette in the range of $30-400 \mathrm{kPa}$ and for pulse durations varying from 0.5 to $6 \mathrm{sec}$. Actuation of the solenoid and control of pulse duration were under microprocessor control.

Electrophysiology. Purinoceptor binding by TNP-ATP and suramin was demonstrated by their antagonism of ATP-induced inward current using whole-cell patch clamp. The whole-cell recordings were obtained as previously described (Housley et al., 1992). Briefly, gigaohm seals were formed using glass micropipettes (Clark Electromedical Instruments, England, GC120TF-10) by bringing the pipette tip into close contact with the basolateral walls of isolated hair cells in the infranuclear region. The membrane patch was then ruptured by the application of gentle suction to allow voltage clamp of the cells in the whole-cell patchclamp mode (after Hamill et al., 1981). The pipettes were filled with an internal solution containing (in mmol/liter) $\mathrm{KCl}, 144 ; \mathrm{MgCl}_{2}, 2 ; \mathrm{NaH}_{2} \mathrm{PO}_{4}$, $1 ; \mathrm{Na}_{2} \mathrm{HPO}_{4}, 8 ; \mathrm{D}$-glucose, 3; EGTA, $1 ; \mathrm{pH}$ adjusted to 7.25 with $1 \mathrm{~N}$ $\mathrm{KOH}$; approximately $300 \mathrm{mOsm}$. Current recordings under voltage clamp were made using a patch-clamp amplifier (Axopatch 200, Axon Instruments) under microprocessor control (pcLAMP 5.5 software, Axon Instruments) via an interface (Tecmar TL-1). Series resistance, cell input resistance, and membrane capacitance were determined from capacitive charging transients elicited by $10 \mathrm{mV}$ hyperpolarizing voltage steps (20 msec) from a holding potential of $-60 \mathrm{mV}$ (after Housley and Ashmore, $1992)$. The mean series resistance $( \pm \mathrm{SEM})$ was $7.7 \pm 0.4 \mathrm{M} \Omega(n=24$; range, 5.2-11.6 M $\Omega$ ). Capacitive charging time constants for the $\mathrm{OHC}$ and IHC were $140 \pm 10 \mu \mathrm{sec}(n=19)$ and $110 \pm 10 \mu \mathrm{sec}(n=5)$, respectively, with ranges of $80-280 \mu \mathrm{sec}$ and $80-120 \mu \mathrm{sec}$. All data were corrected for junction potential and series resistance voltage errors. Cell input resistance varied inversely with respect to OHC length (after Housley and Ashmore, 1992), ranging from 9.4 to $79.9 \mathrm{M} \Omega$ (mean \pm SEM $=27.4 \pm 4.0 \mathrm{M} \Omega, n=19)$. IHC cell input resistance ranged from 27.4 to $132.6 \mathrm{M} \Omega$ (mean $\pm \mathrm{SEM}=77.6 \pm 25.0 \mathrm{M} \Omega, n=5$ ). Membrane capacitance for the $\mathrm{OHC}$ was within the range of $16.5-37.6 \mathrm{pF}(26.1 \pm$ $1.1 \mathrm{pF}, n=19)$, while that for the IHC was $11.3-17.1 \mathrm{pF}(13.4 \pm 1.1$ $\mathrm{pF}, n=5)$. Mean zero current potentials $\left(V_{z}\right)$ were $-62.3 \pm 1.9 \mathrm{mV}$ for $\mathrm{OHC}(n=19)$ and $-58.6 \pm 0.6 \mathrm{mV}$ for $\operatorname{IHC}(n=5)$.

In a further series of electrophysiological experiments, the effect of the divalent cations $\mathrm{Mg}^{2+}$ and $\mathrm{Ca}^{2+}$ on the ATP-elicited inward current in $\mathrm{OHC}$ and IHC was studied. These experiments were designed to support aspects of the fluorescence imaging study in which the presence of the divalent cation-dependent ATP hydrolyzing ectoenzymes on cochlear hair cells was investigated (see next section). Whole-bath superfusion of isolated hair cells was performed with rapid exchange of bath fluids using a four-line inlet to alternately deliver standard external solution, $10 \mu \mathrm{M}$ ATP in standard external solution, divalent cation-free (DCF) external solution, and $10 \mu \mathrm{M}$ ATP in DCF external solution. Each ATP solution was washed from the bath with standard external solution, during which time the cells recovered to their pre-ATP resting membrane potentials. DCF external solution was superfused through the bath before exposure of the cells to $10 \mu \mathrm{M}$ ATP in DCF external solution. Current recordings obtained during voltage ramps $(-150 \mathrm{mV}$ to +100 $\mathrm{mV} ; 1 \mathrm{sec}$ ) were used to calculate the change in membrane conductance during whole-bath superfusion with the two ATP solutions.

Fluorescence imaging. Fluorescence imaging of $\mathrm{IHC}$ and $\mathrm{OHC}$ was achieved using an epifluorescence illumination system fitted to an Nikon TMD inverted microscope. Light generated by a xenon arc lamp (Photon Technology International, $\mathrm{NJ}$ ) was directed through a liquid-filled light guide to the microscope and passed through a filter block (Nikon, BV2B, Japan) for wavelength selection. TNP-ATP exhibits maximal light absorbance at $408 \mathrm{~nm}$ and has a broad spectral emission band that is greatest in the range of 520-570 nm (Hiratsuka and Uchida, 1973; Watanabe and Inesi, 1982). The light was initially band-pass filtered to select the appropriate excitation wavelengths $(400-440 \mathrm{~nm})$, then reflected by a dichroic mirror ( $455 \mathrm{~nm}$ ), and finally focused onto the cell 
through a $63 \times, 1.3 \mathrm{NA}$, oil-immersion objective (335 519861, Leitz, Germany). Emitted fluorescence (either autofluorescence or TNP-ATP induced) was long-pass filtered $(480 \mathrm{~nm})$ and directed to a camera port, where it passed via a relay lens (Nikon, $5-15 \times$ ) to an intensified CCD camera (GenIIsys-CCD72, Dage-MTI). Initial random noise reduction (by $2-4$ frame averaging) and video image enhancement was achieved on line during each experiment using a digital signal processor (DSP200, Dage-MTI). Light-field and fluorescence images were then recorded onto videotape using an sVHS high-resolution video recorder (AG7330 , Panasonic, Japan). Off-line image processing consisted of individual frame capture using a microprocessor-based video-capture board (PCVision Plus, Imaging Technologies) controlled by image analysis software (IMAGe-Pro Plus, Media Cybernetics). Prolonged ( $>1 \mathrm{~min}$ ) exposure of the cells to BV light irradiation was found to induce cell swelling and ultimately cell death, previously attributed to UV-induced frec radical formation and osmotic shock (Dulon et al., 1989). Thus, epifluorescence illumination was limited to the period of drug application and a short (typically 5-10 sec) time window either side of this event by shuttering light via an electronic switching module (Cairn Research, Kent, UK). To minimize photolytic damage, total UV exposure was kept to less than I min. A typical data capture protocol took $20 \mathrm{sec}$ and included $5 \mathrm{sec}$ to determine autofluorescence level, $5 \mathrm{sec}$ of drug application, and $10 \mathrm{sec}$ to observe drug washout. This was repeated up to three times to show TNP-ATP binding-induced fluorescence, alteration in binding by either suramin or divalent cation-free solution, and then recovery of the unblocked TNP-ATP binding after a washout period.

In the final series of imaging experiments the presence of ecto-ATPases, the most likely candidate for TNP-ATP binding-induced fluorescence on the basolateral walls of IHC and OHC, was investigated by removing the divalent cations required for ATP binding to these enzymes. Thus, for experiments involving bath superfusion with DCF external solution, $\mathrm{Mg}^{2+}$ and $\mathrm{Ca}^{2+}$ were omitted from, and $10 \mathrm{mM}$ EDTA added to, the solution, which was delivered to the bath. This allowed sequential superfusion with standard and DCF solutions as demanded by the experimental protocol.

Measurement of pixel intensity [using 8-bit deep gray-scale values in the range of 0 (black) to 255 (white)] was used to evaluate the effect of the divalent cations $\mathrm{Mg}^{2+}$ and $\mathrm{Ca}^{2+}$ and the $\mathrm{P}_{2}$ receptor antagonist suramin on TNP-ATP-induced fluorescence on IHC and OHC. For longitudinal data analysis, a pixel gray-scale transect was made down the center of isolated hair cells. For area analysis, in the case of the divalent cation-free experiments, perimeters were prescribed from the cuticular plate region of the cell to the apical edge of the nucleus, determined from a superimposed light-field image; for suramin quenching studies, stereocilia, cuticular plate, and infracuticular plate-supranuclear, nuclear, and infranuclear areas were prescribed. These regions could be clearly demarcated on the basis of superimposed light-field images and, in addition, the stereocilia, cuticular plate, and nuclear regions were clearly defined by lack of autofluorescence. Sums of pixel intensities per cell were corrected for background autofluorescence and expressed as the sum of pixel intensities $\cdot \mu \mathrm{m}^{-2}$. Student's paired $t$ tests were then used to compare the TNP-ATP-induced fuorescence in the presence of $\mathrm{Mg}^{2+}$ and $\mathrm{Ca}^{2+}$ with that recorded in the absence of these cations in the two hair cell types. A similar analysis was undertaken to evaluate the effect of suramin block of TNP-ATP-induced fluorescence.

\section{Results}

TNP-ATP antagonism of ATP binding

Application of brief pulses $(0.5-5 \mathrm{sec})$ of ATP $(10 \mu \mathrm{M})$ to isolated inner and outer hair cells (voltage clamped at a holding potential of $-60 \mathrm{mV}$ ) produced inward depolarizing current responses similar to those previously recorded in these cell types (Housley et al., 1992, 1993b). However, the TNP-ATP (75-100 $\mu \mathrm{M})$ included with the ATP $(10 \mu \mathrm{M})$ in a second micropipette barrel produced a highly significant block of the ATP response (mean $\pm \mathrm{SEM}=98.8 \pm 0.8 \% ; P<0.01$, Student's paired $t$ test; $n=$ 8 ). Following a short (1-2 $\mathrm{min}$ ) washout period, a second pulse of ATP on its own was again able to elicit a current response, indicating that the TNP-ATP block (in this concentration range) was completely reversible. To determine that the TNP-ATP was indeed acting as a competitive blocker of the ATP response, a graded series of $20 \mathrm{sec}$ exposures of ATP at different concentrations with or without $75 \mu \mathrm{M}$ TNP-ATP was applied to voltage-clamped $\mathrm{OHC}\left(V_{h}=-60 \mathrm{mV}\right)$ by rapid bath superfusion. Consistent with the data obtained using double-barrelled micropipettes, in the presence of TNP-ATP, ATP at 1-10 $\mu \mathrm{M}$ either failed to elicit an inward current response or produced a response that was highly attenuated compared with control responses that exhibited a $K_{d}$ of approximately $12 \mu \mathrm{M}$, in agreement with an earlier analysis by Nakagawa et al. (1990). Concentrations of ATP greater than the coapplied TNP-ATP concentration produced considerable inward current (Fig. 1). Overall, the $K_{d}$ for ATP in the presence of TNP-ATP was displaced by an order of magnitude, consistent with TNP-ATP acting as a competitive blocker of the $\mathrm{P}_{2}$ purinoceptors on hair cells.

\section{Suramin antagonism of ATP binding}

In contrast to the potent antagonism produced by TNP-ATP, suramin blocked only approximately half $(47.3 \pm 5.1 \%$, mean $\pm \mathrm{SEM} ; P<0.001$, Student's $t$ test; $n=7 \mathrm{OHC}, 1 \mathrm{IHC}$; range 16.3-69.6\%) of the ATP-induced inward current, even at relatively high concentrations $(250 \mu \mathrm{M}$ to $1 \mathrm{mM})$. Isolated hair cells were voltage clamped at $-60 \mathrm{mV}$ and brief pulses of $10 \mu \mathrm{M}$ ATP $(0.5-5 \mathrm{sec})$ applied. As described above, this produced a characteristic inward depolarizing current that persisted for the duration of the pulse. The cells returned to steady state membrane current following a 1-2 min washout. When a second pulse of ATP was reapplicd together with suramin through an adjacent micropipette barrel, the partial blockage of the ATPinduced inward current was achieved (Fig. 2). As shown in the third trace of Figure 2, this antagonism could be reversed following a further 1-3 min washout. Recovery of ATP responses after suramin were to between $-16 \%$ and $+27 \%$ of the presuramin, control ATP responses. There was no significant difference between control and recovery ATP responses $(P>0.05$, Student's $t$ test), indicating that the suramin block was reversible.

\section{Effect of divalent cations on the ATP-gated conductance}

The effect of the divalent cations $\mathrm{Mg}^{2+}$ and $\mathrm{Ca}^{2+}$ on the ATPinduced inward current, and hence ATP binding, in IHC ( $n=$ 5) and $\mathrm{OHC}(n=4)$ was investigated. Isolated hair cells were voltage clamped at $-60 \mathrm{mV}$ and sequential whole-bath superfusion with $10 \mu \mathrm{M}$ ATP in standard and DCF external solutions performed. Mean slope conductances were measured by calculating the slope of the current response between $-80 \mathrm{mV}$ and $-60 \mathrm{mV}$ during $1 \mathrm{sec}$ voltage ramps $(-150 \mathrm{mV}$ to $+100 \mathrm{mV})$ before and during superfusion with the drug. Applied voltages were corrected for voltage error due to series resistance and resting slope conductances were subtracted to give the change in conductance due to ATP. The mean ( \pm SEM) resting slope conductances in standard and DCF external solutions for IHC was $12.2 \pm 4.0 \mathrm{nS}$ and $51.8 \pm 17.6 \mathrm{nS}$, respectively, while that for $\mathrm{OHC}$ was $24.0 \pm 5.4 \mathrm{nS}$ and $170.8 \pm 101.6 \mathrm{nS}$, respectively. During the application of ATP in standard solution the slope conductance increased by $33.7 \pm 16.8 \mathrm{nS}$ (IHC) and $24.4 \pm 8.6$ $\mathrm{nS}(\mathrm{OHC})$. This compared to a mean increase of $144.9 \pm 107.5$ $\mathrm{nS}$ (IHC) and $151.5 \pm 93.1 \mathrm{nS}$ (OHC) elicited by ATP in DCF external solution in addition to the changes in baseline conductance produced by the DCF solution alone. There was no significant difference between the ATP-mediated conductance changes of each group of hair cells in either standard or DCF external solutions (Student's paired $t$ test), although the mean increases considerably in the DCF solution. 
A.
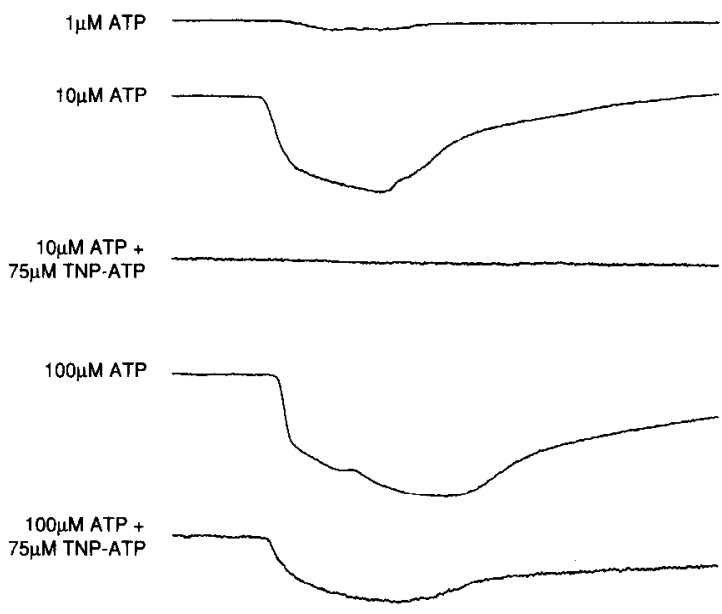

$\ln A$

B.

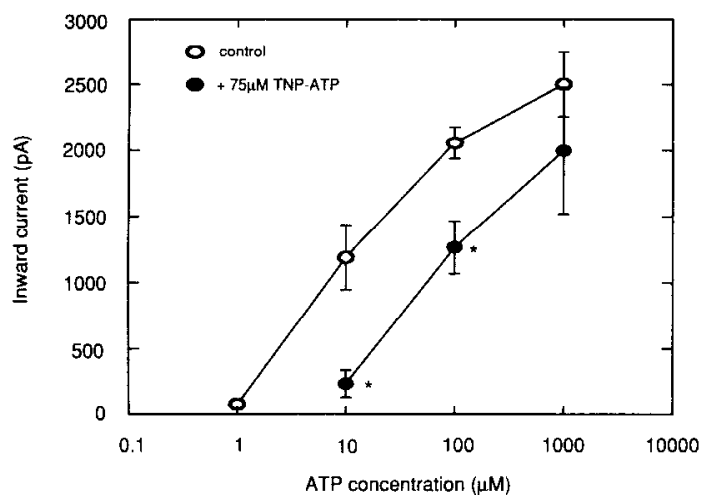

Figure 1. Competitive binding of ATP and its fluorescent analog TNPATP at the $\mathrm{P}_{2}$ purinoceptor binding site. $A$, Responses to ATP and ATP + TNP-ATP $(75 \mu \mathrm{M})$ applied for $20 \mathrm{sec}$ by rapid bath superfusion (10 $\mu \mathrm{l} / \mathrm{sec}$ ) to an isolated outer hair cell voltage clamped at $-63 \mathrm{mV}$ (standing current $+390 \mathrm{pA}$ ). Note that the inward current with TNP-ATP + $10 \mu \mathrm{M}$ ATP $(-59 \mathrm{pA})$ was less than that elicited by 1 м ATP alone $(-195 \mathrm{pA})$, whereas TNP-ATP + ATP at $100 \mu \mathrm{M}$ produced a large inward current $(-1401 \mathrm{p} \Lambda) . B$, Dose-response data based on studies similar to that shown above. Note that the $K_{d}$ of the control data is approximately $12 \mu \mathrm{M}$, whereas the dose-response curve is shifted to the right by approximately 1 order of magnitude in the presence of $75 \mu \mathrm{M}$ TNP-ATP, indicating competitive binding. Data represent the averaged current responses for the final $10 \mathrm{sec}$ of drug application (mean $\pm \mathrm{SEM}$; 10 and $100 \mu \mathrm{M}$ ATP, $n=3$ cells; 1 and $1000 \mu \mathrm{M}$ ATP, $n=2$ cells). *, significant difference based on a Student's $t$ test, $P<0.02$. The bath was designed for laminar flow; volume $=75 \mu \mathrm{l}$.

\section{Imaging of $P_{2}$ purinoceptors}

The binding of the fluorescent TNP-ATP was visualized microscopically under epifluorescence illumination as described. All cells imaged exhibited some autofluorescence that was most predominant in the infracuticular region (Fig. $3 C$ ), although it could also be seen over much of the remainder of the cell, most notably in the infranuclear region (e.g., Figs. $4 B, 5 B$ ). Autofluorescence within the infracuticular region corresponds to the

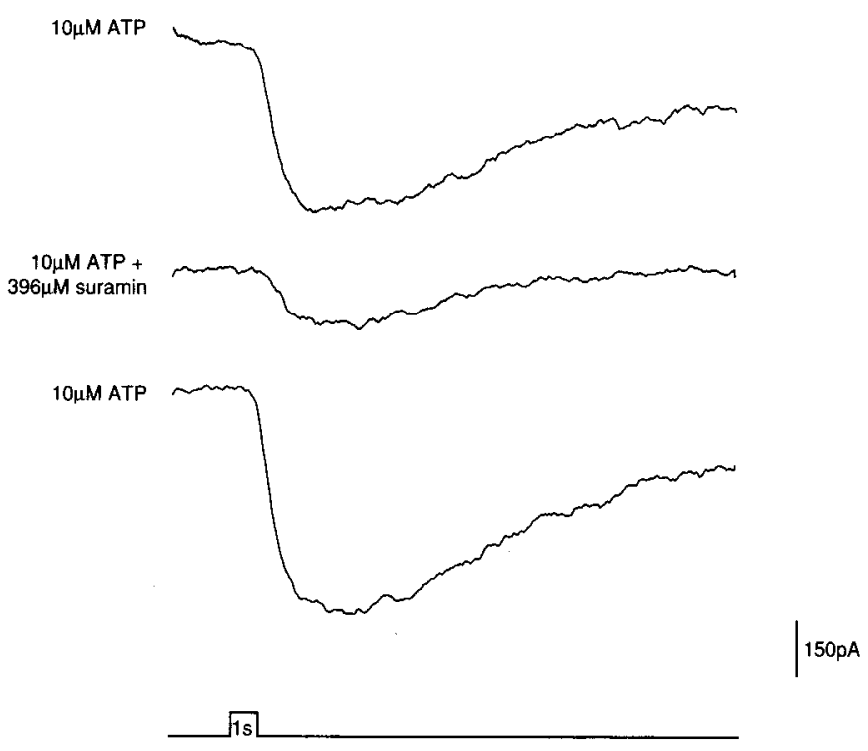

Figure 2. Evidence for competitive binding of ATP and suramin at $\mathrm{P}_{2}$ purinoceptor sites on an isolated outer hair cell. The top current trace shows the inward depolarizing current $(-435 \mathrm{pA})$ elicited when a $1 \mathrm{sec}$ ATP $(10 \mu \mathrm{M})$ pulse was applied to the cell under voltage clamp $(-54$ $\mathrm{mV}$ ). As the middle current trace shows, this ATP-induced current was substantially reduced $(67 \%)$ by a second ATP pulse applied together with suramin $(396 \mu \mathrm{M})$. This antagonism was reversible with washout (1-3 min), as shown in the bottom trace. Steady state current $=-487$ pA.

area of greatest density of mitochondria in hair cells (Ikeda and Takasaka, 1993) and is principally attributable to flavoproteins (Aubin, 1979; Benson et al., 1979; Sewell and Mroz, 1993). It was, however, noticeably absent from the cuticular plate itself (see also Ikeda and Takasaka, 1993). In both inner and outer hair cells the application of a pulse of TNP-ATP $(1-6 \mathrm{sec})$ under epifluorescence illumination produced an instantaneous and substantial increase in observed fluorescence. While areas exhibiting autofluorescence (principally infracuticular and infranuclear regions) showed increased fluorescence during application of TNP-ATP, the most significant finding was the emittance of fluorescence from areas where previously little or no autofluorescence was detectable. These areas included the stereocilia bundle, apical surface, and lateral margins of the cuticular plate and lateral cell membrane over and above the nucleus (Figs. 35). This extremely rapid change in fluorescence is consistent with binding of TNP-ATP to extracellular ATP binding sites rather than labeling of mitochondria because the charge on nucleotides and derivatives such as TNP-ATP precludes rapid diffusion across the cell membrane (Dubyak, 1991) and the readily reversible washout of TNP-ATP is indicative of maintained cell integrity (see also Fig. 10). Background levels of fluorescence were low, with TNP-ATP (at $75 \mu \mathrm{M}$ ) exhibiting little fluorescence in the external solution. Immediately following the pulse of TNP-ATP, the intensity of induced fluorescence began to decline with washout $(400 \mu \mathrm{l} / \mathrm{min})$ and had essentially returned to levels comparable to those observed for autofluorescence following 10-20 sec. This pattern of TNP-ATP-induced fluorescence could be observed on both cell types even after applying multiple pulses of TNP-ATP to individual cells.

\section{Differentiation of ATP binding sites}

Visualization of TNP-ATP binding-induced fluorescence revealed that extracellular ATP binding sites were more wide- 

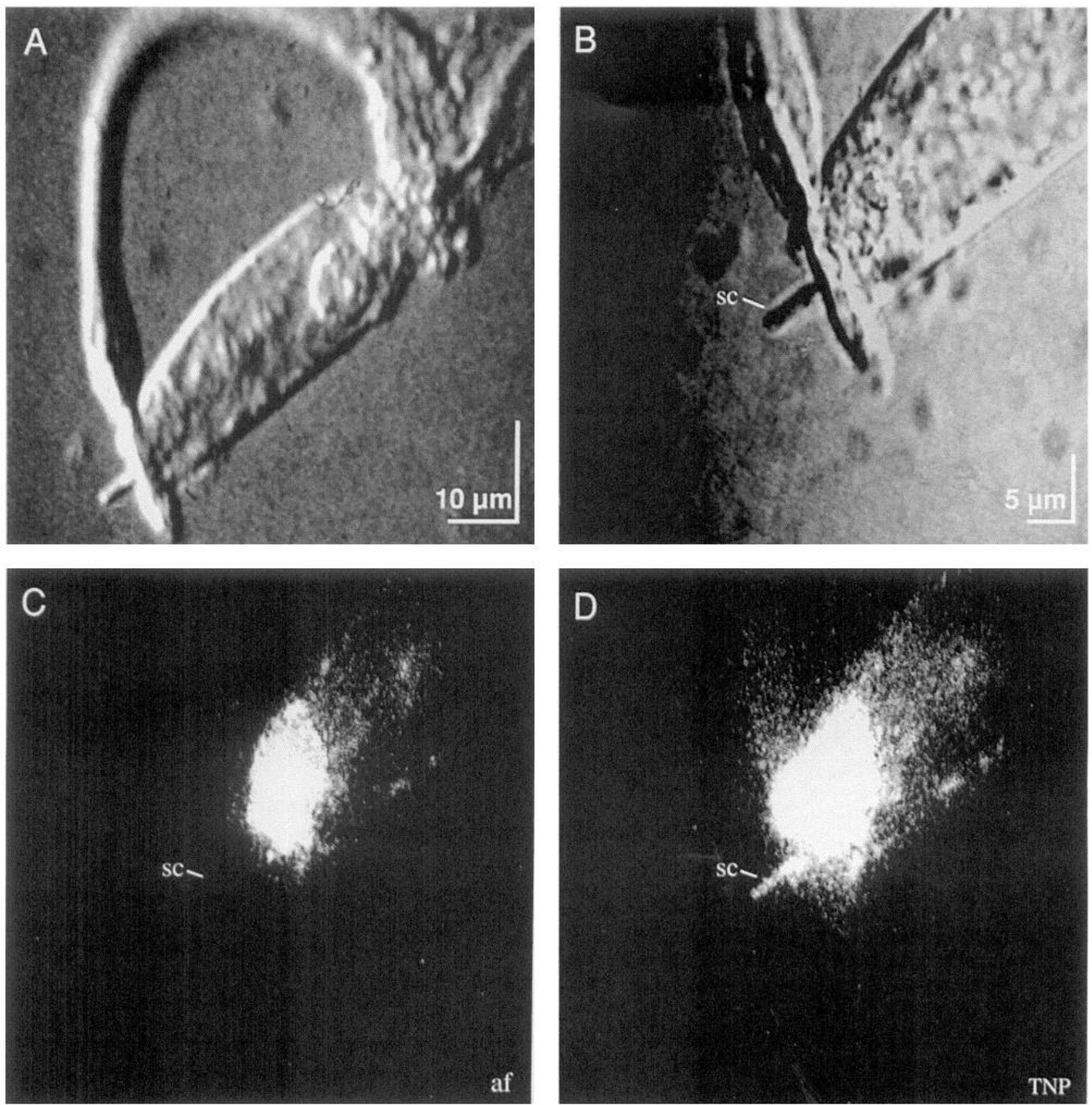

Figure 3. Videomicrographs of an isolated OHC following application of TNP-ATP. A, Light-field view imaged with Nomarski differential interference contrast optics showing the $\mathrm{OHC}$ with attached Deiter's cell. B. High-power light-field view of the OHC apical pole showing the stereocilia bundle $(s c)$, cuticular plate, infracuticular region, and the region of the Deiter's cell attached to the lateral margin of the cuticular plate. $C$, Autofluorescence $(a f)$ from the OHC under epifluorescence illumination. $D$, TNP-ATP-induced fluorescence (TNP; $75 \mu \mathrm{M}, 4$ sec pulse). There was significant enhancement of fluorescence on the stereocilia bundle $(s c)$, cuticular plate, and infracuticular region. A small increase in fluorescence was also seen on the Deiter's cell process.

spread than indicated by previous electrophysiological studies that had localized the $P_{2}$ purinoceptors to the apical surface and stereocilia (Housley et al., 1992, 1993b). The following procedures were performed to classify what appeared to be different classes of ATP binding sites.

Purinoceptors. Differentiation of TNP-ATP binding to $\mathrm{P}_{2}$ purinoceptors from binding to other extracellular ATP binding sites was achieved by quenching the TNP-ATP-induced fluorescence with the nonselective $P_{2}$ purinoceptor antagonist suramin. Application of TNP-ATP to IHC (Fig. 4) and OHC (Fig. 5) induced fluorescence on the stereocilia, cuticular plate, and basolateral membrane, principally in the infracuticular and infranuclear regions (Figs. $4 C, 5 C, 6 A$ ). When TNP-ATP was reapplied to the same cells together with suramin $(250-500 \mu \mathrm{M})$ via a second micropipette barrel, the fluorescence was quenched by $57 \%$ on the stereocilia $(P<0.05$, Student's paired $t$ test; $n=5)$. Fluorescence in the cuticular plate region was reduced by $23 \%$ with suramin block $(P>0.05)$ and quenching in other regions of the cells was negligible (Figs. $4 D, 5 D, 6$ ).

Putative ecto-ATPase binding. To examine whether the TNP- 

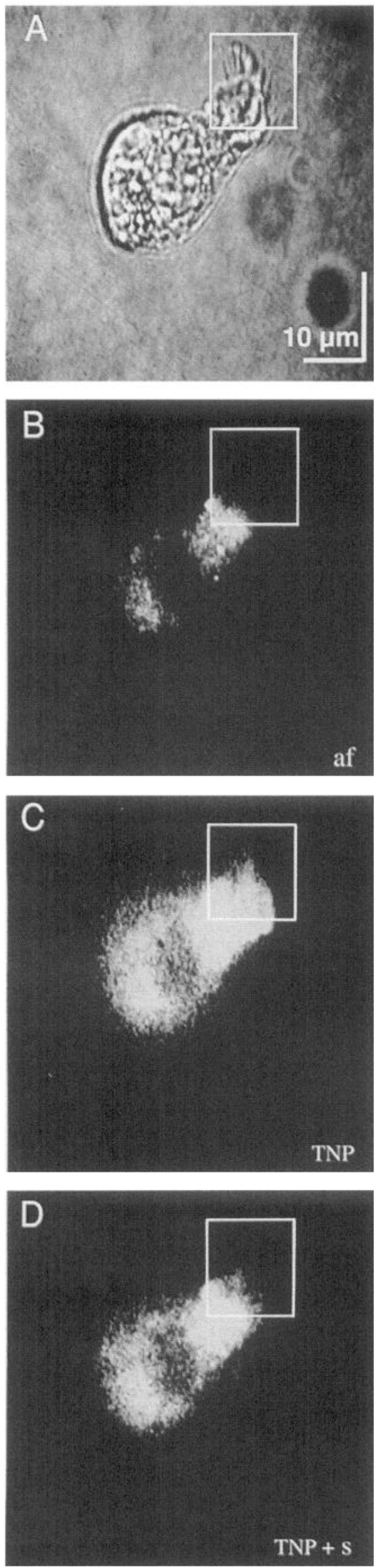
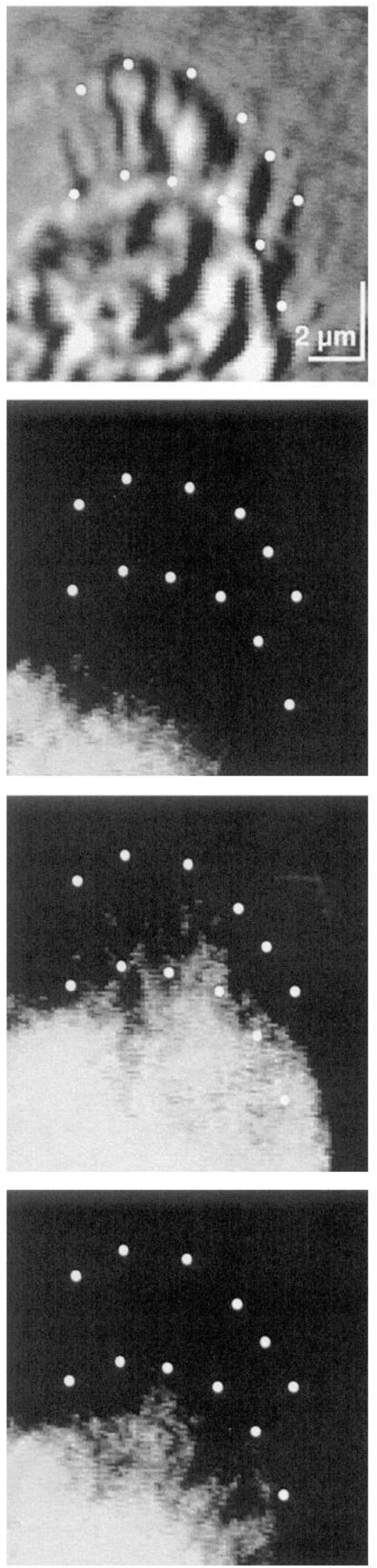

Figure 4. Quenching of TNP-ATPinduced fluorescence on an IHC by the nonselective $\mathrm{P}_{2}$ purinoceptor antagonist suramin. The videomicrographs on the right show magnified views of the stereocilia and cuticular plate areas outlined by the white boxes. The white dots in each panel illustrate the position of the stereocilia. $A$, Light-field image of an IHC. $B$, Autofluorescence (af) exhibited by the cell. In this cell the most intense autofluorescence was confined to the infracuticular and infranuclear regions. $C$, Fluorescence induced by TNP-ATP (75 $\mu \mathrm{M}, 4 \mathrm{sec}$ pulse). The left panel (TNP) shows binding of the ATP analog over most of the cell, including the stereocilia and cuticular plate (right panel). D, Quenching of TNP-ATP-induced fluorescence by $500 \mu \mathrm{M}$ suramin $(T N P+s)$. Suramin was coapplied with TNP-ATP onto the cell after a short washout period following the TNP-ATP pulse depicted in $C$. The left panel shows that there is little quenching of TNPATP-induced fluorescence emitted from the body of the cell, while the right panel clearly shows a substantial quenching of the fluorescence on the stereocilia and apical surface of the cuticular plate. 

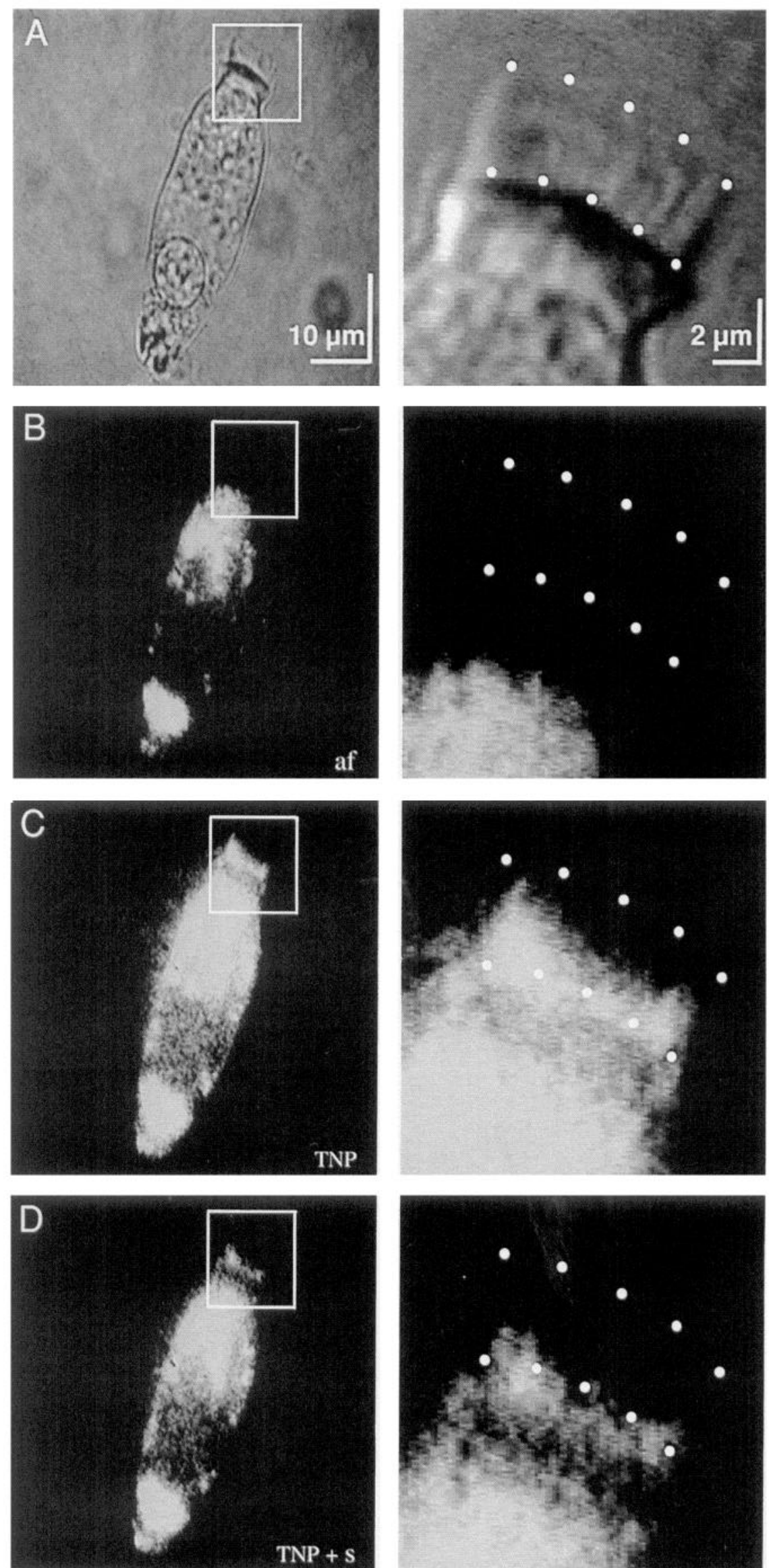

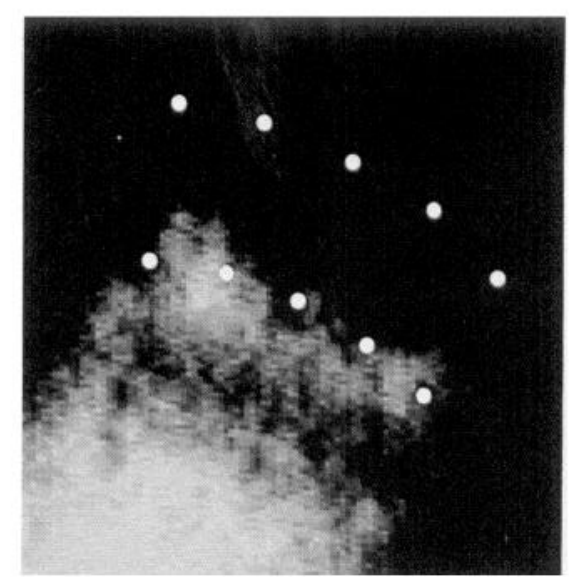

Figure 5. Quenching of TNP-ATPinduced fluorescence on an $\mathrm{OHC}$ by the $\mathrm{P}_{2}$ purinoceptor antagonist suramin. The arrangement of videomicrographs and the figure markings are the same as for Figure 4. A, Light-field image of an $\mathrm{OHC}$. The cell structures within the white box include the infracuticular region, cuticular plate, and stereocilia bundle. $B$, Autofluorescence $(a f)$ exhibited by the cell. $C$, TNP-ATP $(75 \mu \mathrm{M})-$ induced fluorescence. The left panel (TNP) shows that, like the IHC, binding of the ATP analog has occurred over most of the cell, including the stereocilia, cuticular plate, and infracuticular region. $D$, Quenching of TNP-ATP-induced fluorescence by suramin $(250 \mu \mathrm{M})$. A similar protocol to that for Figure 4 was followed in these experiments. The left panel shows that there was little quenching by suramin of TNP-ATPinduced fluorescence emitted from the body of the OHC, while the right panel again clearly shows a substantial quenching of the fluorescence on the stereocilia and cuticular plate. The quenching of TNP-ATP-induced fluorescence by suramin was reversible with washout (not shown). 
A.

$\mathrm{OHC}$

\section{IHC}

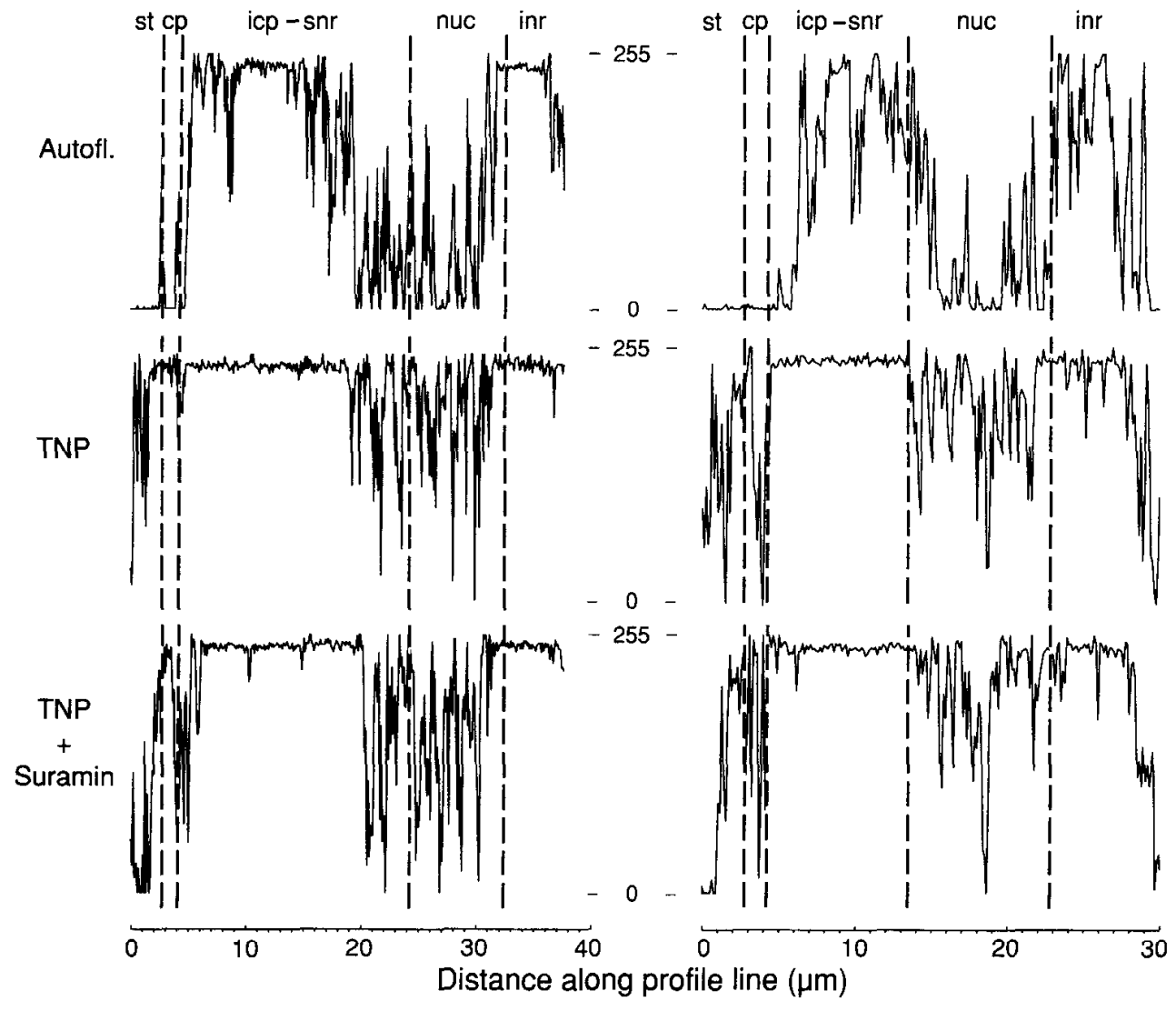

Figure 6. Fluorescence intensity analysis of various regions of inner and outer hair cells before and during the application of TNP-ATP and TNP-ATP coapplied with suramin. $A$, Examples of intensity line profiles through an $\mathrm{OHC}$ and an IHC. Using image analysis software, a longitudinal line was drawn through the center of each cell from the stereocilia (point $0 \mu \mathrm{m}$ ) to the base of the cell, and the intensity of cach pixel on that line measured and plotted. This was a gray-scale analysis, where each pixel ranged in value from 0 (black) to 255 (white). Note that the substantial suramin-induced reduction in TNPATP-induced fluorescence in the region of the stereocilia of each cell was not repeated in other regions of these cells. $B$, Histogram of combined fluorescence intensity data (corrected for autofluorescence levels) derived from identified cell regions of IHC $(n=3)$ and $\mathrm{OHC}(n=2)$. Fluorescence intensity was measured as the mean sum of pixel intensity $\cdot \mu \mathrm{m}^{-2}$. The bars represent the mean $( \pm$ SEM). Note that only TNP-ATP-induced fluorescence on the stereocilia was significantly reduced (by $57 \%$ ) when coapplied with suramin $(P$ $<0.05$, Student's paired $t$ test; $n=5$ ), while fluorescence emitted from other regions of these cells under these conditions was largely unaffected by suramin. $s t$, stereocilia; $c p$, cuticular plate; $i c p-s n r$, combined infracuticular plate and supranuclear regions; nuc, nuclear region; inr, infranuclear region; autofl. autofluorescence. Regions were determined by prescribing perimeters using superimposed light-field images, and also by the lack of autofluorescence in the stereocilia and the cuticular plate, and limited autofluorescence in the nuclear region.

ATP-induced fluorescence not quenched by suramin, and therefore presumably not attributable to $P_{2}$ purinoceptor binding, was due to binding to ecto-ATPases, we investigated the known divalent cation $\left(\mathrm{Mg}^{2+}\right.$ and $\left.\mathrm{Ca}^{2+}\right)$ dependency of these enzymes as an identifying characteristic (Culic et al., 1990; Barry, 1992). TNP-ATP-induced fluorescence on both inner (Fig. 7C) and outer (Fig. $8 \mathrm{C}$ ) hair cells was similar to that observed in previous experiments. In all 14 cells, fluorescence on the basolateral membrane region was quenched when a second pulse of TNPATP was applied in the absence of divalent cations (superfusion with DCF external solution) (Figs. 7D, 8D). Reperfusion of the bath with standard external solution reestablished the higher levels of TNP-ATP fluorescence (Fig. 9) that washed out within seconds of stopping drug flow, indicating maintenance of cellular integrity over the brief exposure to divalent cation-free solution.

Pixel intensity analysis of TNP-ATP-induced fluorescence on both hair cell types under standard and DCF conditions (Fig. 9) revealed that there were significant differences between these treatments with respect to labeling of the basolateral membrane. Control values (obtained in the presence of $\mathrm{Mg}^{2+}$ and $\mathrm{Ca}^{2+}$ ) for 

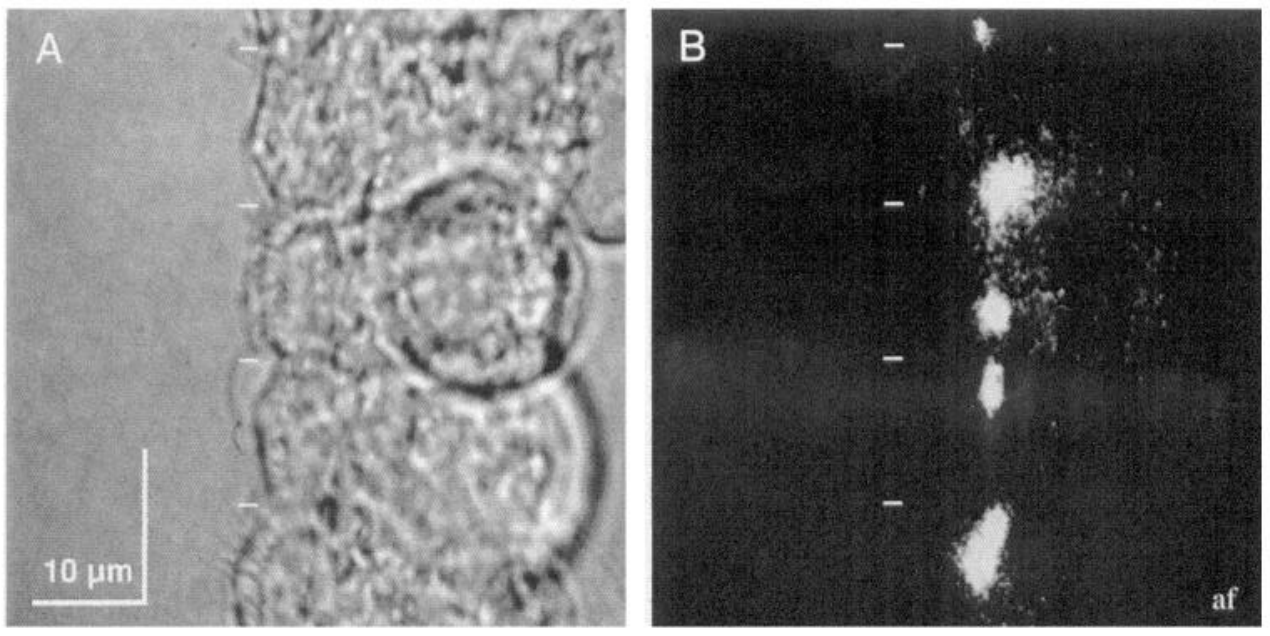

Figure 7. Videomicrographs showing the effect of removing the divalent cations $\mathrm{Mg}^{2+}$ and $\mathrm{Ca}^{2+}$ from the bath perfusate on TNP-ATP-induced fluorescence on a row of inner hair cells. $A$, Light-field image of a row of inner hair cells. The lateral margins of each cell in the row are indicated by the horizontal white lines. $B$, Autofluorescence ( $a f)$ exhibited by the cells under epifluorescence illumination. $C$, TNP-ATP-induced fluorescence (TNP; $75 \mu \mathrm{M} ; 5 \mathrm{sec})$ on the inner hair cells in the presence of the two divalent cations. Fluorescence seen here was comparable to that observed on inner hair cells in other experiments. $D$, Quenching of TNPATP-induced fluorescence in the absence of divalent cations $(T N P-d c)$. Compared to $C$, a significant reduction in the intensity of fluorescence resulted from the removal of divalent cations (see also Fig. 9). $E$, Recovery of TNPATP-induced fluorescence after $3 \mathrm{~min}$ of resuperfusion with normal solution. $F$, Image after $9 \mathrm{sec}$ of washout of the TNP-ATP labeling shown in $E$; consistent with maintenance of cell integrity throughout the experimental procedure.
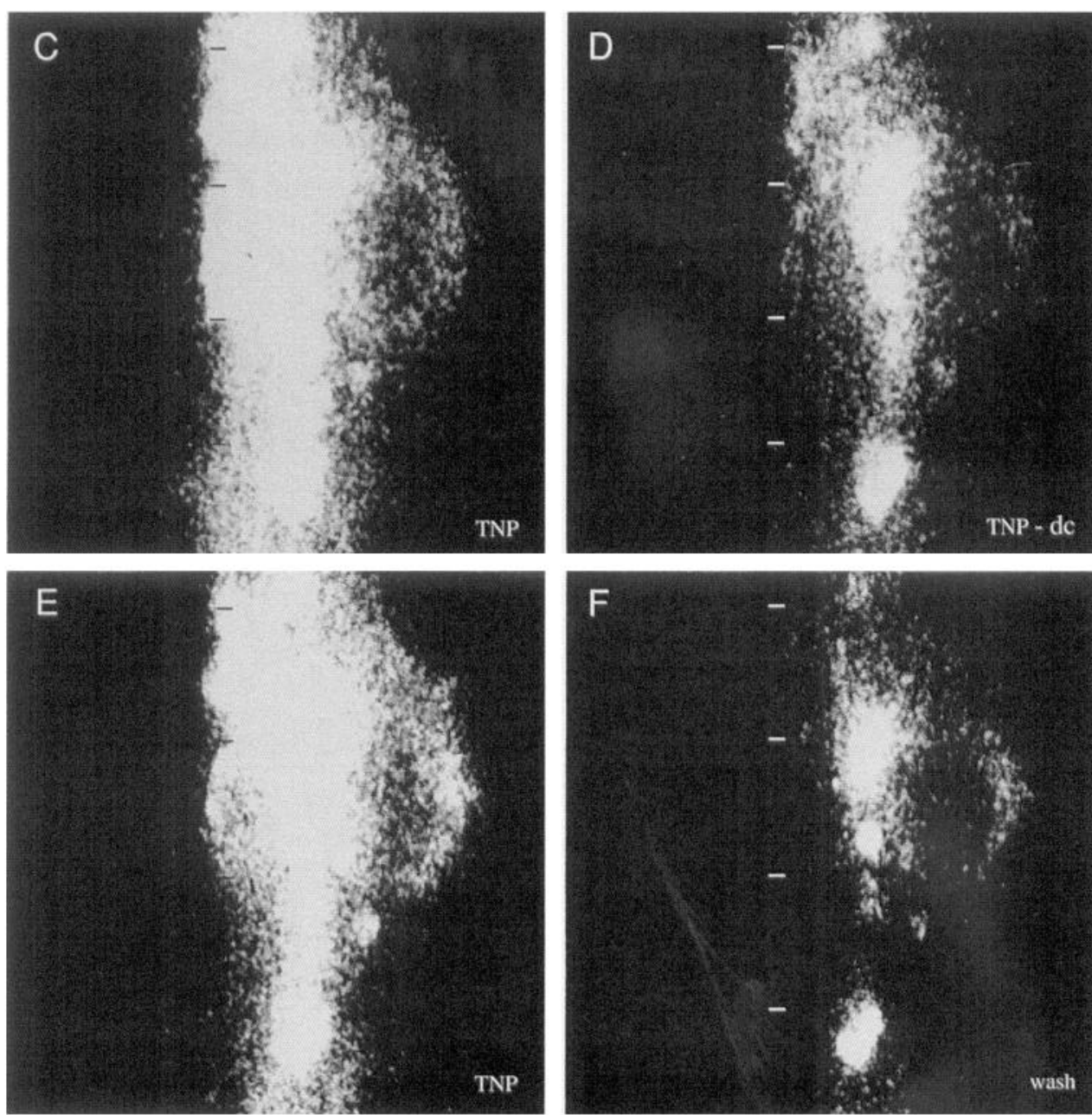

both inner $(n=8)$ and outer $(n=6)$ hair cells were significantly greater than those obtained after a subsequent $3 \mathrm{~min}$ washout with divalent cation-free solution $(P<0.001$ and $P<0.01$, respectively), which reduced IHC TNP-ATP fluorescence by $74 \%$ and $\mathrm{OHC}$ binding by $32 \%$. Reperfusion of the bath with standard external solution for a further $3 \mathrm{~min}$ resulted in a significant recovery of fluorescence when TNP-ATP was reapplied $(P<0.01$, IHC; $P<0.05$, OHC) such that, at least for the $\mathrm{OHC}$, there was no significant difference between the control and recovery TNP-ATP pulses in standard external solution.
An additional analysis to compare pixel intensities between IHC and OHC demonstrated that the TNP-ATP-induced fluorescence on the basolateral membrane of IHC was significantly more intense $(162 \%)$ than that observed on OHC $(P<0.01$, Student's $t$ test) (compare Figs. 7, 8; see also Fig. 9B).

\section{Cellular internalization of $T N P-A T P$}

In contrast to the specific and reversible localization of TNPATP-induced fluorescence observed on freshly isolated cells, those whose condition had deteriorated or that had been ex- 

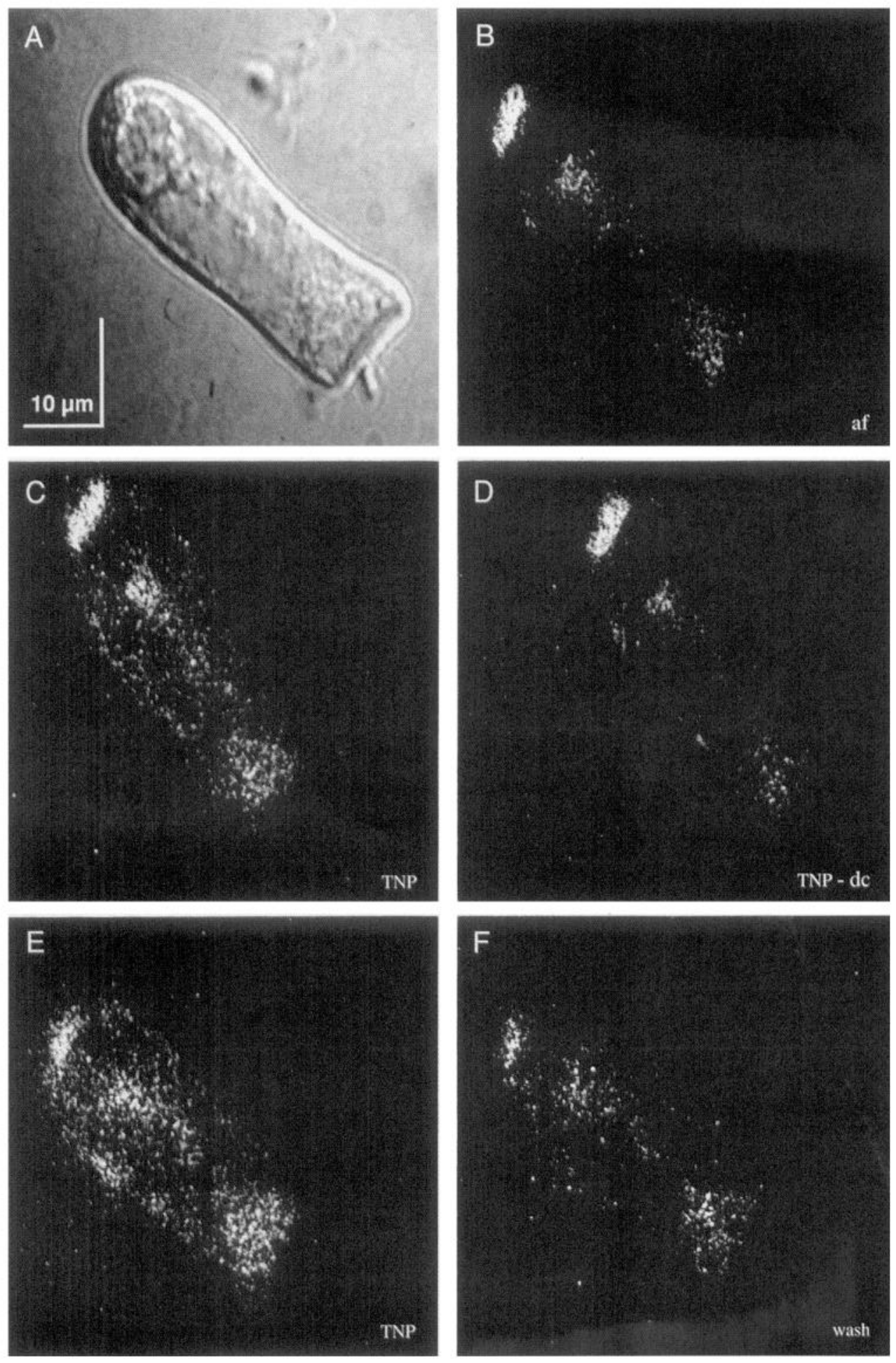

Figure 8. Videomicrographs showing the effect of removing the divalent cations $\mathrm{Mg}^{2+}$ and $\mathrm{Ca}^{2+}$ from the bath perfusate on TNP-ATP-induced fluorescence on an isolated outer hair cell. $A$, Light-field image. $B$, Autofluorescence $(a f)$ exhibited by the cell under epifluorescence illumination. $C$, TNP-ATPinduced fluorescence $(T N P ; 75 \mu \mathrm{M})$ in the presence of divalent cations. $D$, Quenching of TNP-ATP-induced fluorescence in the absence of divalent cations $(T N P-d c)$. As shown for the inner hair cells in Figure 7, the absence of $\mathrm{Mg}^{2+}$ and $\mathrm{Ca}^{2+}$ in the external solution resulted in a significant quenching of the TNP-ATP-induced fluorescence on outer hair cells (see also Fig. 9). E, Recovery of TNP-ATP-induced fluorescence after $3 \mathrm{~min}$ of resuperfusion with normal solution. $F$, Image indicating rapid washout of the labeling, consistent with maintenance of cell integrity throughout the experimental procedure.

posed to prolonged BV light irradiation often exhibited a nonspecific pattern of intense and persistent fluorescence when exposed to TNP-ATP. In those cells showing normal cell morphology (IHC, flask shape with centrally located nucleus; $\mathrm{OHC}$, cylindrical shape with basally located nucleus) and physiological membrane potentials $\left(V_{z}>-30 \mathrm{mV}\right)$, TNP-ATPinduced fluorescence was localized to the cuticular plate, infracuticular and infranuclear regions, and stereocilia, and was transient as previously described. However, in cells whose resting membrane potential was near $0 \mathrm{mV}$ with associated abnormal morphology (swelling, nucleus migration, condensed nuclear membrane, observed rupture of the cell membrane), the fluorescence involved the whole cell and was persistent, even after prolonged periods of washout. In cells whose membrane was observed to rupture following cell swelling, a wave of fluorescence was often initiated at the point of rupture that then spread to involve the whole cell.

This change in fluorescence pattern is clearly shown in a hair 
A.

Figure 9. Fluorescence intensity analysis of various regions of inner and outer hair cells before and during the application of TNP-ATP in standard and DCF external solutions. $A$, Intensity line profiles through $\mathrm{OHC}$ and IHC. This was achieved in a manner similar to that described in the legend of Figure 6. Stereocilia were not included in the analysis as they were either superimposed on, and therefore indistinguishable from, other regions of the cell (IHC) or did not exhibit substantial fluorescence due to their diffuse nature that results in the fluorescence signal falling below the detection threshold of each pixel $(O H C)$. Note that the fluorescence induced by TNP-ATP in standard external solution $(T N P+d c)$ was significantly reduced when TNP-ATP was reapplied in the absence of these cations $(T N P-d c)$. This was particularly evident in the IHC that gave a substantially more intense response than the OHC. $B$, Histogram showing the effect of divalent cations $\left(\mathrm{Mg}^{2+}\right.$ and $\left.\mathrm{Ca}^{2+}\right)$ on TNP-ATP-induced fluorescence on the cuticular plate to supranuclear region of inner and outer hair cells. This region of the basolateral membrane was chosen for analysis because it could be clearly identified in all cells examined. The bars represent the mean $( \pm$ SEM) TNP-ATP-induced fluorescence on isolated inner $(n=8)$ and outer $(n=6)$ hair cells (corrected for autofluorescence levels) before (Control), during $(D C F)$, and after (Recovery) divalent cation-free solution perfusion. Fluorescence was measured as the mean sum of pixel intensity $\cdot \mu \mathrm{m}^{-2}$. Control values were significantly greater than those obtained at the end of a 3 min perfusion with DCF solution $(P<0.001$ IHC, $P$ $<0.01 \mathrm{OHC}$, Student's paired $t$ test), an effect that was reversible as shown by the significant recovery of fluorescence following reperfusion with standard external solution $(P<0.01$ IHC, $P<0.05$ OHC, Student's paired $t$ test). Note the significantly greater level of TNP-ATP fluorescence on IHC compared with $\mathrm{OHC}$, indicative of a higher density of putative ecto-ATPase sites. $c p-s n r$, combined cuticular plate to supranuclear regions; $n u c$, nuclear region; inr, infranuclear region; autofl., autofluorescence; $d c$, divalent cations.
OHC
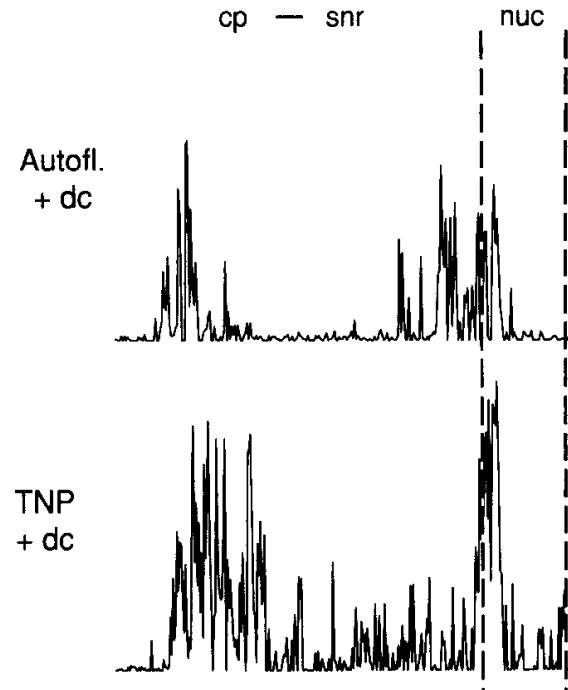

TNP

$-\mathrm{dc}$

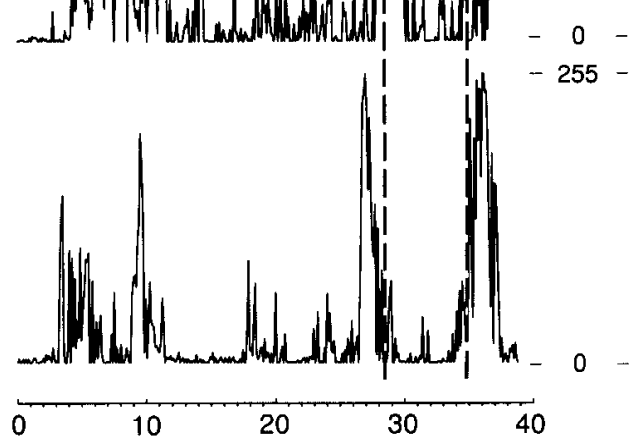

0

10

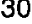

40

0

Distance along profile line $(\mu \mathrm{m})$

B.

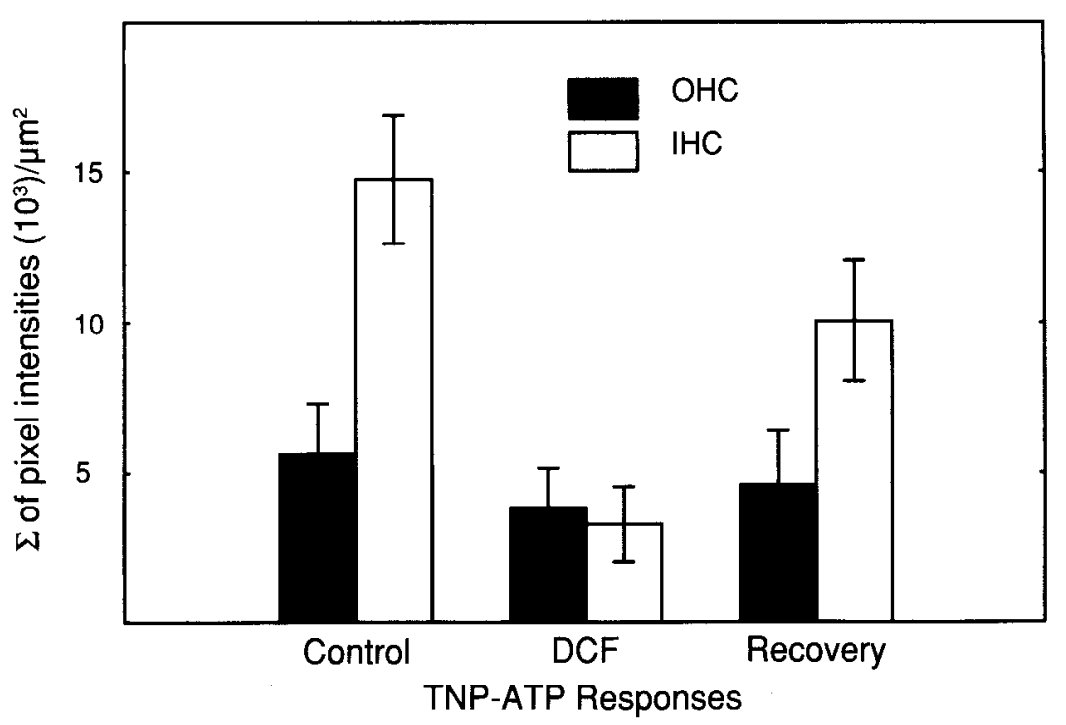

cell that deteriorated during the course of a whole-cell patchclamp experiment (Fig. 10). When the cell's membrane potential had fallen to $0 \mathrm{mV}$, intense TNP-ATP-induced fluoresccnce developed that was persistent and extended throughout the cell. This is consistent with the internalization of TNP-ATP when the cell membrane becomes permeable upon cell death, indicating that the localized fluorescence seen in apparently healthy cells was limited to the extracellular surface.

\section{Discussion}

This study is the first to usc a visual marker to demonstrate the subcellular location of extracellular ATP binding sites. The specificity of binding of the fluorescent ATP analog TNP-ATP was determined by selective quenching experiments. The effect of the $\mathrm{P}_{2}$ purinoceptor antagonist suramin, and removal of the divalent cations required for ATP binding to ATPases, provides 

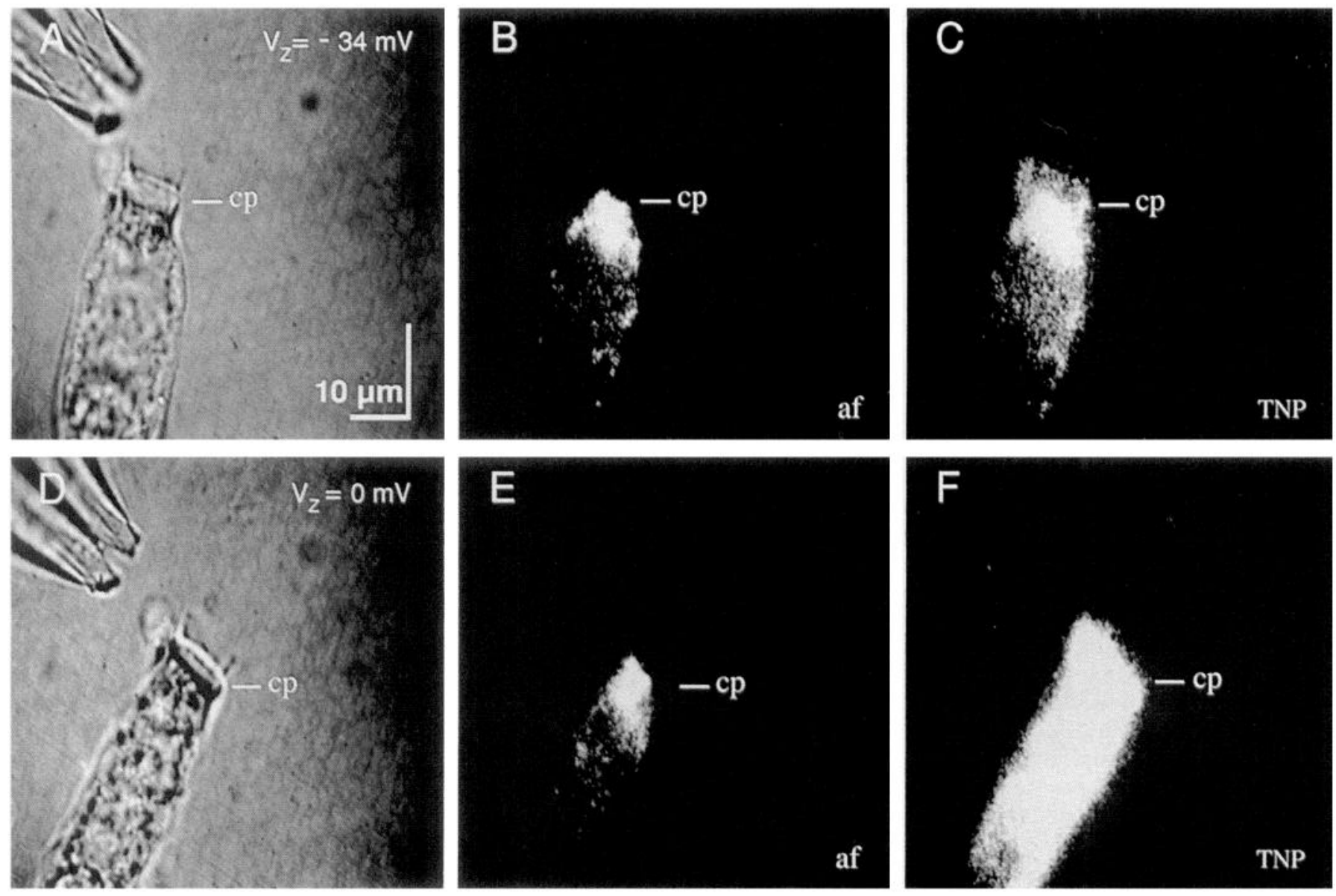

Figure 10. Evidence for localization of binding of TNP-ATP to the extracellular surface of vital cochlear hair cells. A, Light-field image of an isolated outer hair cell. This cell's resting membrane potential was $-34 \mathrm{mV}$, recorded concurrently with the imaging using a whole-cell patchclamp micropipette attached to the base of the cell (not visible). A double-barrelled drug pipette (upper left) contained $10 \mu \mathrm{M}$ ATP and $75 \mu \mathrm{M}$ TNPATP. Prior to imaging this cell under epifluorescence illumination, a $1 \mathrm{sec}$ pulse of $10 \mu \mathrm{M}$ ATP applied to the cell, voltage clamped at $-60 \mathrm{mV}$, evoked a $-759 \mathrm{pA}$ inward current $\left(\mathrm{P}_{2}\right.$ purinoceptor response) that confirmed the presence of extracellular ATP receptors. $c p$, cuticular plate. $B$, Autofluorescence $(a f)$ emitted by the cell under epifluorescence illumination. $C$, TNP-ATP-induced fluorescence emitted during a 6 sec pulse. Note the increase in fluorescence in the infracuticular region, cuticular plate, and stereocilia. $D$, Light-field image of the same cell shown in $A$ after its membrane potential had fallen to $0 \mathrm{mV}$, indicating cell death. Note also the elongation of the cell and condensed cell membrane, both characteristics of cell death. $E$, Autofluorescence exhibited by the dead cell. $F$, Internalization and binding of TNP-ATP to intracellular ATP binding sites resulted in extensive and persistent fluorescence emitted from all regions of the cell.

evidence for localization of $\mathrm{P}_{2}$ purinoceptors to the apical surface of cochlear hair cells and distribution of ecto-ATPases over the basolateral membrane region.

It has been demonstrated previously that the application of ATP to isolated cochlear hair cells elicits an inwardly rectifying current by gating a nonselective cation channel (Ashmore and Ohmori, 1990; Nakagawa et al., 1990; Housley et al., 1992, 1993b; Lin et al., 1993). This study has shown that TNP-ATP blocks this current, thus establishing, at least in cochlear hair cells, that this analog is a more effective antagonist of ATP binding to purinergic receptor sites than the competitive $P_{2}$ purinoceptor antagonist suramin (Dunn and Blakeley, 1988; Nakazawa et al., 1990, 1991; Henning et al., 1992; Silinsky et al., 1992). This finding is supported by the recent report of displacement of isothiocyanate from $\mathrm{P}_{2}$ receptors by TNP-ATP (Soltoff et al., 1993). Preliminary experiments precluded use of ATP as an agent to determine the specificity of TNP-ATP binding-induced fluorescence because we observed an enhancement rather than a reduction in fluorescence over the hair cells when $100 \mu \mathrm{M}$ ATP was added to the TNP-ATP. This phenomenon has been well characterized in studies involving ATPase systems and appears due to an interaction of ATP and TNP-ATP at the binding site (Watanabe and Inesi, 1982). However, low-affinity electrostatic binding of TNP-ATP to phospholipids has been reported to be minimal (Moezydlowski and Fortes, 1981). We were also precluded from using reactive blue 2 , an alternative $P_{2}$ receptor blocker (Inoue and Nakazawa, 1992), to quench the $\mathrm{P}_{2}$ receptor component of ATP binding sites because it exhibited considerable intrinsic fluorescence, in the micromolar concentration range, over the wavelengths used for detection of TNPATP binding. The significant block of the stereocilia TNP-ATP binding $(57 \%)$ by suramin is highly suggestive of specific binding of the TNP-ATP to $\mathrm{P}_{2}$ purinoceptors localized to this region. The level of block obtained with suramin is comparable to that achieved in a recent imaging study localizing NMDA receptors to isolated neurons (Benke et al., 1993) utilizing a fluorescent derivative of conotoxin-G (CntxG), with specific block achieved with a thousand-fold excess of native $\mathrm{CnTxG}$. In the present study, a caveat to the evidence for $\mathrm{P}_{2}$ purinoceptor localization to the stereocilia of hair cells is the possibility of undetermined 
(nonspecific) interactions of TNP-ATP with the glycocalyx of the hair cells, given previous evidence for attraction of charged molecules by this region (see Santi and Anderson, 1987, for a review).

Our study represents a novel application for TNP-ATP, which was originally synthesized and used in fluorescence studies of intracellular ATPase kinetics (Hiratsuka and Uchida, 1973; Watanabe and Inesi, 1982). Intracellular enzyme systems studied with this ATP analog include $\mathrm{Ca}^{2+}$-ATPases of skeletal muscle sarcoplasmic reticulum (Scott, 1985; Berman, 1986), mitochondrial ATPases (Grubmeyer and Penefsky, 1981a,b), and mitochondrial cytochrome c oxidase (Reimann and Kadenbach, 1992). None of the previous studies utilized the sensitivity of intensified videocamera technology to achieve real-time subcellular localization of TNP-ATP binding in living cells. Such technology has proved invaluable for imaging low receptor numbers.

Our finding of $\mathrm{P}_{2}$ purinoceptor localization fully complements both the recent demonstration by Ashmore et al. (1993) that the initiation point for $\mathrm{Ca}^{2+}$ entry during application of ATP to isolated $\mathrm{OHC}$ is confined to the stereocilia, and previous electrophysiological data we obtained that also precludes a basolateral distribution of the ATP-gated ion channels in isolated cochlear hair cells. In the latter studies (Housley et al., 1992, 1993b) we reported that, under voltage clamp, ATP applied focally from a micropipette elicited an inward current of maximum amplitude and minimum latency only when delivered to the apical (endolymphatic) surface of the hair cells. ATP applied to the basal pole of these cells elicited smaller currents with longer latencies, consistent with ATP diffusing from the site of application to the apically located binding sites.

In the present imaging study, a small amount of quenching produced by suramin on the basolateral surface of some inner and outer hair cells, while not significant overall (see Fig. 6), may have resulted from an inhibition of ATP binding to ectoATPases. Although inhibition of nucleotide binding to an ectoenzyme by suramin has not been reported in the literature, suramin has been shown to inhibit the activity of a number of intracellular enzymes (Wills and Wormall, 1950), including an intracellular $\mathrm{Na}^{+}-\mathrm{K}^{+}$-activated ATPase (Fortes et al., 1973). In the latter study, however, it was not established whether suramin achieved this effect through an inhibition of ATP binding or through some other inhibitory mechanism. Thus the results from the present study, taken with the previous electrophysiological data, suggest that if suramin does inhibit ATP binding to ecto-ATPases, it is only a weak effect.

Further evidence in support of the designation of the cuticular plate and basolateral TNP-ATP-induced fluorescence being due to ecto-ATPases arises from the sensitivity of this fluorescence to quenching by removal of $\mathrm{Ca}^{2+}$ and $\mathrm{Mg}^{2+}$ from the bathing medium. One characteristic property of these ectoenzymes is their dependence on the presence of the divalent cations $\mathrm{Ca}^{2+}$ and $\mathrm{Mg}^{2+}$ for binding and subsequent hydrolysis of ATP to occur (Nagy, 1986; Zimmermann et al., 1986; Culic et al., 1990; Barry, 1992). In the present study, the significant quenching of TNPATP-induced fluorescence on the basolateral membrane in the absence of these divalent cations and the subsequent significant recovery of fluorescence following retesting with TNP-ATP in standard external solution provides strong evidence that this labeling is indeed attributable to ecto-ATPases. TNP-ATP binding to $P_{2}$ purinoceptors is unlikely to have been affected, as no significant difference between the ATP-induced increase in membrane conductance in either standard or DCF bathing so- lution was found to occur. The presence of ecto-ATPases on apical structures of hair cells, however, cannot be ruled out by these experimental results.

While previously undetected in hair cell sensory systems, the existence of ecto-ATPases may not be surprising given the widespread distribution of this enzyme system. These membranebound enzymes with their ATP hydrolyzing site on the extracellular surface have been found on a wide range of cell types and membrane preparations, including cholinergic nerve terminals (Zimmermann et al., 1986), endothelial cells (see Gordon, 1986, for review), renal cortical membrane vesicles (Sabolic et al., 1992), hepatocytes (Lin, 1989), and smooth muscle cells (see Cusack et al., 1988, for review). In conjunction with other ectonucleotidases, ecto-ATPases are responsible for initiating the complete hydrolysis of ATP to adenosine (Zimmermann et al., 1986), but are not associated with membrane transport (Lin, 1990).

That TNP-ATP was most likely binding to extracellular sites and not crossing the cell membrane to bind intracellularly was demonstrated by our internalization study. The principal feature of TNP-ATP-induced fluorescence on live cochlear hair cells was its transient appearance, persisting for only a few seconds after the pressure-applied drug pulse. In contrast, TNP-ATP applied to dead cells rapidly crossed the cell membrane and spread throughout the cell, producing an intense and persistent fluorescence as the analog bound to the multitude of intracellular ATP binding sites. This inability to cross the cell membrane of live cells is perhaps not surprising since there is no evidence of mechanisms for transporting ATP across the cell membrane (Nagy, 1986; Cusack et al., 1988) and ATP itself is prevented from crossing the cell membrane by any other means, principally due to its four negative charges (Cusack et al., 1988). This property of TNP-ATP has important practical implications and has made possible our novel use of TNP-ATP as a fluorescent marker of extracellular ATP binding sites on live cells.

Although the role of ecto-ATPases in cochlear hair cells and other cell types is unknown, it is possible to speculate on two likely functions, based on studies in other systems. The first is to regulate $\mathrm{P}_{2}$ purinoceptor function by terminating the effect of ATP through its hydrolysis. Such a role has been suggested by other workers (Nagy, 1986; Lin and Russell, 1988) and indeed would be an essential process if ATP acted as a neurotransmitter or neuromodulator (Edwards et al., 1992; Evans et al., 1992). The localization of the $P_{2}$ purinoceptors to the endolymphatic surface of these cells, however, suggests that ATP acts in a humoral rather than a neural role. Given the apparent wide distribution of ecto-ATPases on cochlear hair cells, it is possible that within the endolymphatic space their role may be to terminate $\mathrm{P}_{2}$ purinoceptor activation, while the widespread distribution of the ecto-ATPases over the perilymphatic cell surface suggests a significant role in the dephosphorylation of ATP to adenosine. Zimmerman et al. (1986) demonstrated that this process occurred in isolated nerve endings and that the translocated adenosine was incorporated into new nucleotides, including ATP located within synaptic vesicles. Our observation that putative ecto-ATPase sites are in considerably greater abundance on IHC basolateral membrane compared with the $\mathrm{OHC}$ (as shown by the significantly more intense labeling with TNPATP on IHC) may relate to the role of the IIIC in glutamatergic neurotransmission (see Eybalin, 1993, for review), where purines may have a protective and regulatory function (Rudolphi et al., 1992).

As indicated, the role and source of ATP in the mammalian 


\section{Proposed model for extracellular ATP interactions with cochlear hair cells}

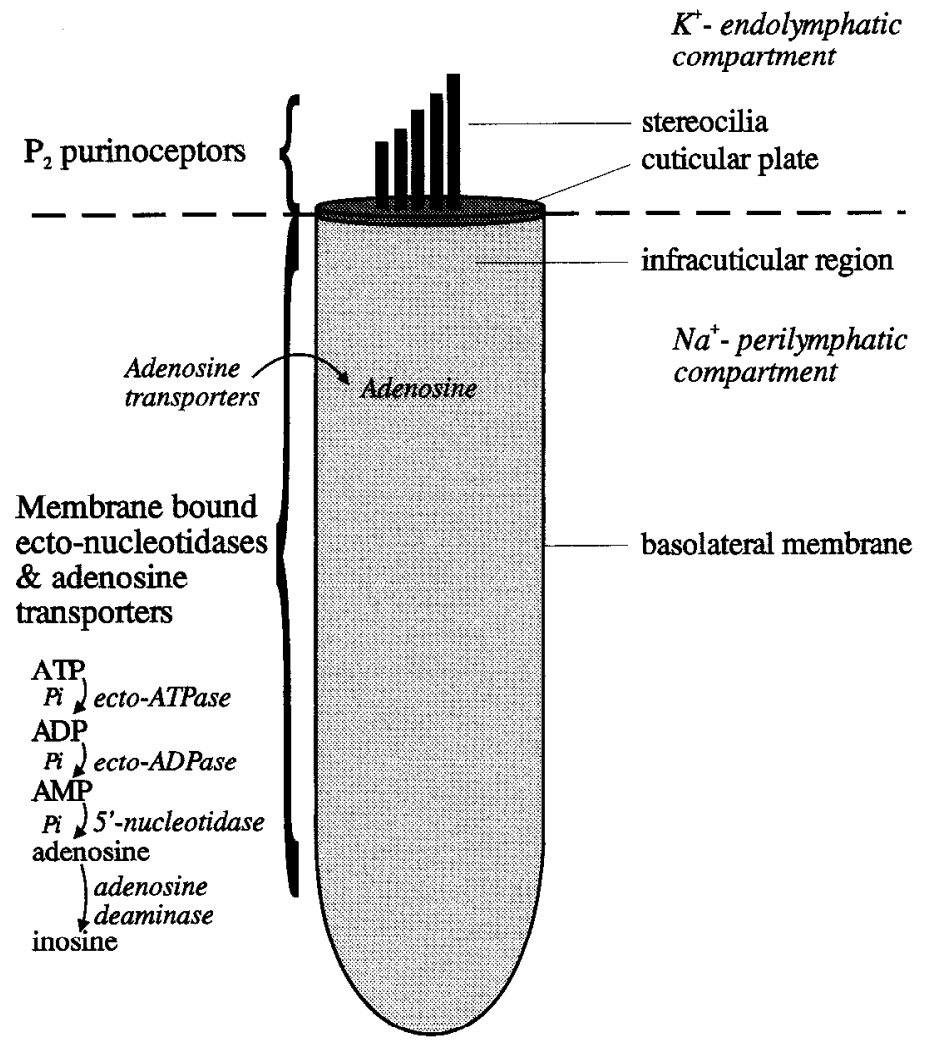

Figure 11. Based on the findings of this study, we propose a model for extracellular ATP interactions on cochlear hair cells that features two distinct populations of extracellular ATP binding sites. $P_{2}$ purinoceptors are located in the endolymphatic compartment on the apical cell membrane, specifically the stereocilia, and gate a nonselective cation channel. The second population consists of membrane-bound ectoATPases located on the basolateral membrane in the perilymphatic compartment, which by analogy to other systems may be associated with additional ectonucleotidases hydrolyzing extracellular ATP to adenosine for subsequent transport into the cell. cochlea is presently unknown. In addition to the now wellestablished electrophysiological effects of $P_{2}$ purinoceptors on sensory hair cells, there is also evidence of ATP exerting effects (mainly increases in $\left[\mathrm{Ca}^{2+}\right]_{\mathrm{i}}$ ) on supporting cells of the organ of Corti (Deiter's cells, Hensen's cells, outer pillar cells), thereby suggesting that they too have $\mathrm{P}_{2}$ purinergic receptors (Ashmore and Ohmori, 1990; Kolston and Ashmore, 1992; Moataz et al., 1992; Dulon et al., 1993). The evidence that $P_{2}$ purinoceptors are located only on hair cell structures located within the endolymphatic compartment and that a wide variety of cells possess these receptors suggests that ATP released into the endolymph may exert complex multicellular effects on the hearing process. Even at the level of the individual OHC, ATP-induced depolarization and intracellular calcium loading (Ashmore and Ohmori, 1990; Shigemoto and Ohmori, 1990; Housley et al., 1992) must affect both forward and reverse transduction processes (Ashmore, 1990), by altering the driving force and input resistance that generate the receptor potential, altering the operating point for the nonlinear electromotility present in these cells (Brownell et al., 1985; Ashmore, 1987; Holley and Ashmore, 1988; Santos-Sachi, 1989, 1991, 1992; Dallos et al., 1991; Kalinec et al., 1992; Mammano and Ashmore, 1993), and activation of contractile protein-based structural changes (Dulon and Schacht, 1992). Discovery of the source of ATP is likely to help in the understanding of the extracellular role of this nucleotide. ATP is known to be released from red blood cells and endothelial cells, particularly under conditions of ischemia and/ or hypoxia (Gordon, 1986; Burnstock, 1993b). One possible origin is the stria vascularis, the tissue forming the lateral wall of the scala media that generates $\mathrm{K}^{+}$-rich endolymphatic fluid. Our in vivo studies demonstrate physiological levels of ATP within the fluids of the cochlea that are increased during shortterm hypoxia (Thorne et al., 1993). Further in vivo and in vitro studies, including the functional investigation of ecto-ATPase activity in this tissue, are required to answer these challenging questions.

In summary, we present evidence that two distinct classes of ATP binding sites exist on cochlear sensory hair cells, based on imaging of fluorescence emitted on binding of an analog of ATP, TNP-ATP. Electrophysiologically validated selective quenching studies suggest that $P_{2}$ purinoceptors are localized to the region of the stereocilia, while putative ecto-ATPase sites are distributed over much of the basolateral membrane. Based on studies in other tissues (Gordon, 1986; Zimmerman et al., 1986) it could be anticipated that a family of ectonucleotidase enzymes are present on the basolateral surface of hair cells in addition to ecto-ATPases (Fig. 11), dephosphorylating adenine nucleotides to adenosine that is then taken up into cells by specific membrane-bound adenosine transporters (Centelles et al., 1992). The latter elements in this model have not been investigated in the present study but warrant further attention.

\section{References}

Ashmore JF (1987) A fast motile response in guinea-pig outer hair cells: the cellular basis for the cochlear amplifier. J Physiol (Lond) 388:323-347. 
Ashmore JF (1990) Forward and reverse transduction in the mammalian cochlea. Neurosci Res [Suppl] 12:s39-s50.

Ashmore JF, Ohmori H (1990) Control of intracellular calcium by ATP in isolated outer hair cells of the guinea-pig cochlea. J Physiol (Lond) 360:397-422.

Ashmore JF, Kolston PJ, Mammano F (1993) Dissecting the outer hair cell feedback loop. In: Biophysics of hair cell sensory systems (Duifhuis H, Horst JW, van Dijk P, van Netten SM, eds), pp 151157. Singapore: World Scientific.

Aubin JE (1979) Autofluorescence of viable cultured mammalian cells. J Histochem Cytochem 27:36-43.

Barnard EA, Burnstock G, Webb TE (1994) G protein-coupled receptors for ATP and other nucleotides: a new receptor family. Trends Pharmacol Sci 15:67-70.

Barry MA (1992) Ecto-calcium-dependent ATPase activity in mammalian taste bud cells. J Histochem Cytochem 40:1919-1928.

Bean BP, Friel DD (1990) ATP-activated channels in excitable cells. In: Ion channels (Narahashi T, ed), pp 169-203. New York: Plenum.

Benke TA, Jones OT, Collingridge GL, Angelides KJ (1993) $\mathrm{N}$-methylD-aspartate receptors are clustered and immobilized on dendrites of living cortical neurons. Proc Natl Acad Sci USA 90:7819-7823.

Benson RC, Meyer RA, Zaruba ME, McKhann GM (1979) Cellular autofluorescence-is it due to flavins? J Histochem Cytochem 27:44 48.

Berman MC (1986) Absorbance and fluorescence properties of $2^{\prime}\left(3^{\prime}\right)$ $O$-(2,4,6-trinitrophenyl)adenosine $5^{\prime}$-triphosphate bound to coupled and uncoupled $\mathrm{Ca}^{2+}$-ATPase of skeletal muscle sarcoplasmic reticulum. J Biol Chem 261:16494-16501.

Brownell WE, Bader CR, Bertrand D, de Ribeaupierre Y (1985) Evoked mechanical responses of isolated outer hair cells. Science 227:194 196.

Burnstock G (1972) Purinergic nerves. Pharmacol Rev 24:509-581.

Burnstock $G$ (1990) Noradrenaline and ATP as cotransmitters in sympathetic nerves. Neurochem Int 17:357-368.

Burnstock G (1993a) Physiological and pathological roles of purines: an update. Drug Dev Res 28:195-206.

Burnstock G (1993b) Hypoxia, endothelium, and purines. Drug Dev Res 28:301-305.

Centelles JJ, Cascante M, Canela EI, Franco R (1992) A model for adenosine transport and metabolism. Biochem J 287:461-472.

Culic O, Sabolic I, Zanic-Grubisic T (1990) The stepwise hydrolysis of adenine nucleotides by ectoenzymes of rat renal brush-border membranes. Biochim Biophys Acta 1030:143-151.

Cusack NJ, Hourani SMO, Welford LA (1988) The role of ectonucleotidases in pharmacological responses to nucleotide analogues. In: Adenosine and adenine nucleotides: physiology and pharmacology (Paton DM, ed), pp 93-100. London: Taylor and Francis.

Dallos P, Evans BN, Hallworth R (1991) Nature of the motor element in electrokinetic shape changes of cochlear outer hair cells. Nature 350:155-157.

Drury AN, Szent-Györgyi A (1929) The physiological activity of adenine compounds with special reference to their action upon the mammalian heart. J Physiol (Lond) 68:213-237.

Dubyak GR (1991) Signal transduction by $P_{2}$-purinergic receptors for extraccllular ATP. Am J Resp Cell Mol Biol 4:295-300.

Dulon D, Schacht J (1992) Motility of cochlear outer hair cells. Am J Otol 13:108-112.

Dulon D, Zajic G, Schacht J (1989) Photo-induced irreversible shortening and swelling of isolated cochlear outer hair cells. Int J Radiat Biol 55:1007-1014.

Dulon D, Mollard P, Aran JM (1991) Extracellular ATP elevates cytosolic $\mathrm{Ca}^{2+}$ in cochlear inner hair cells. Neuroreport 2:69-72.

Dulon D, Moataz R, Mollard P (1993) Characterization of $\mathrm{Ca}^{2+}$ signals generated by extracellular nucleotides in supporting cells of the organ of Corti. Cell Calcium 14:245-254.

Dunn PM, Blakeley AGH (1988) Suramin: a reversible $P_{2}$-purinoceptor antagonist in the mouse vas deferens. Br J Pharmacol 93:243245.

Edwards FA, Gibb AJ, Colquhoun D (1992) ATP receptor-mediated synaptic currents in the central nervous system. Nature 359:144-147.

Evans RJ, Derkach V, Surprenant A (1992) ATP mediates fast synaptic transmission in mammalian neurons. Nature 357:503-505.

Eybalin M (1993) Neurotransmitters and neuromodulators of the mammalian cochlea. Physiol Rev 73:309-373.

Fortes PAG, Ellory JC, Lew VL (1973) Suramin: a potent ATPase inhibitor which acts on the inside surface of the sodium pump. Biochim Biophys Acta 318:262-272.

Gordon JL (1986) Extracellular ATP: effects, sources and fate. Biochem J 233:309-319.

Gordon JL (1990) The effects of ATP on endothelium. In: Biological actions of extracellular ATP (Dubyak GR, Fedan JS, eds), pp 46-52. New York: New York Academy of Sciences.

Grubmeyer C, Penefsky HS (1981a) The presence of two hydrolytic sites on beef heart mitochondrial adenosine triphosphatase. J Biol Chem 256:3718-3728.

Grubmeyer C, Penefsky HS (1981b) Cooperativity between catalytic sites in the mechanism of action of beef heart mitochondrial adenosine triphosphatase. J Biol Chem 256:3728-3734.

Hamill OP, Marty A, Neher E, Sakmann B, Sigworth FJ (1981) Improved patch clamp techniques for high resolution current recording from cells and cell-free membrane patches. Pfluegers Arch 391:85100.

Henning RH, Nelemans A, van den Akker J, den Hertog A (1992) The nucleotide receptors on mouse $\mathrm{C} 2 \mathrm{C} 12$ myotubes. Br J Pharmacol 106:853-858.

Hiratsuka T, Uchida K (1973) Preparation and properties of $2^{\prime}$ (or 3')$O$-(2,4,6-trinitrophenyl) adenosine $5^{\prime}$-triphosphate, an analog of adenosine triphosphate. Biochim Biophys Acta 320:635-647.

Holley MC, Ashmore JF (1988) On the mechanism of a high-frequency force generator in outer hair cells isolated from the guinea-pig cochlea. Proc R Soc Lond [Biol] 232:413-429.

Housley GD, Ashmore JF (1992) Ionic currents of outer hair cells isolated from the guinea-pig cochlea. J Physiol (Lond) 448:73-98.

Housley GD, Greenwood D, Ashmore JF (1992) Localization of cholincrgic and purinergic receptors on outer hair cells isolated from the guinea-pig cochlea. Proc R Soc Lond [Biol] 249:265-273.

Housley GD, Greenwood D, Mockett BG (1993a) Localization and characterization of adenosine-5'-triphosphate receptors on inner hair cells isolated from the guinea-pig cochlea. IUPS 32:278.31/P.

Housley GD, Greenwood D, Mockett BG, Munoz DJB, Thorne PR (1993b) Differential actions of ATP-activated conductances in outer and inner hair cells isolated from the guinea-pig organ of Corti: a humoral purinergic influence on cochlear function. In: Biophysics of hair cell sensory systems (Duifhuis H, Horst JW, van Dijk P, van Netten SM, eds), pp 116-123. Singapore: World Scientific.

Ikeda K. Takasaka T (1993) Confocal laser microscopical images of calcium distribution and intracellular organelles in the outer hair cell isolated from the guinea pig cochlea. Hearing Res 66:169-176.

Illes P, Nörenberg W (1993) Ncuronal ATP receptors and their mechanism of action. Trends Pharmacol Sci 14:50-54.

Inoue K, Nakazawa K (1992) ATP receptor-operated $\mathrm{Ca}^{2+}$ influx and catecholamine release from neuronal cells. News Pharmacol Sci 7:5659.

Kalinec F, Holley MC, Iwasa KH, Lim DJ, Kachar B (1992) A membrane-based force generation mechanism in auditory sensory cells. Proc Natl Acad Sci USA 89:8671-8675.

Kolston PJ, Ashmore JF (1992) Action of ATP on isolated Hensen's cells of guinea-pig cochlea investigated by calcium imaging and wholecell recording. J Physiol (Lond) 446:389P.

Lin SH (1989) Localization of the ecto-ATPase (ecto-nucleotidase) in the rat hepatocyte plasma membrane. J Biol Chem 264:14403-14407.

Lin SH (1990) Liver plasma membrane ecto-ATPase: purification, localization, cloning and functions. In: Biological actions of extracellular ATP (Dubyak GR, Fedan JS, eds), pp 394-400. New York: New York Academy of Sciences.

Lin SH, Russell WE (1988) Two $\mathrm{Ca}^{2+}$-dependent ATPases in rat liver plasma membrane. J Biol Chem 263:12253-12258.

Lin X, Hume RI, Nuttall AL (1993) Voltage-dependent block by neomycin of the ATP-induced whole cell current of guinea-pig outer hair cells. J Neurophysiol 70:1593-1605.

Mammano F, Ashmore JF (1993) Reverse transduction measured in the isolated cochlea by laser Michelson interferometry. Nature 365: $838-841$.

Moataz R, Saito T, Dulon D (1992) Evidence for voltage sensitive $\mathrm{Ca}^{2+}$ channels in supporting cells of the organ of Corti: characterization by indo-1 fuorescence. Adv Biosci 83:53-59.

Moezydlowski EG, Fortes PAG (1981) Characterization of $2^{\prime}, 3^{\prime}-O$ (2,4,6-trinitrocyclohexadienylidine)adenosine $5^{\prime}$-triphosphate as a fluorescent probe of the ATP site of sodium and potassium transport adenosine triphosphatase. J Biol Chem 256:2346-2356. 
Nagy A (1986) Enzymatic characteristics and possible role of synaptosomal ecto-adenosine triphosphatase from mammalian brain. In: Cellular biology of ectoenzymes (Kreutzberg GW, Reddington M, Zimmermann H, eds), pp 49-59. Berlin: Springer.

Nakagawa T, Akaike N, Kimitsuki T, Komune S, Arima T (1990) ATP-induced current in isolated outer hair cells of guinea pig cochlea. J Neurophysiol 63:1068-1074.

Nakazawa K, Fujimori K, Takanaka A, Inoue K (1990) Reversible and selective antagonism by suramin of ATP-activated inward current in PCI2 phaeochromocytoma cells. Br J Pharmacol 101:224-226.

Nakazawa K, Inoue K, Fujimori K, Takanaka A (1991) Effects of ATP antagonists on purinoceptor-operated inward currents in rat phaeochromocytoma cells. Pfluegers Arch 418:214-219.

Reimann A, Kadenbach B (1992) Stoichiometric binding of 2'(or 3')$O$-(2,4,6-trinitrophenyl)adenosine 5'-triphosphate to bovine heart cytochrome c oxidase. FEBS Lett 307:294-296.

Rudolphi KA, Schubert P, Parkinson FE, Fredholm BB (1992) Adenosine and brain ischemia. Cerebrovasc Brain Metab Rev 4:346-369.

Sabolic I, Culic O, Lin SH, Brown D (1992) Localization of ectoATPase in rat kidney and isolated renal cortical membrane vesicles. Am J Physiol 262:F217-F228.

Santi PA, Anderson CB (1987) A newly identified surface coat on cochlear hair cells. Hearing Res 27:47-65.

Santos-Sacchi J (1989) Asymmetry in voltage-dependent movements of isolated outer hair cells from the organ of Corti. J Neurosci 9:2954 2962.

Santos-Sacchi J (1991) Reversible inhibition of voltage-dependent outer hair cell motility and capacitance. J Neurosci 11:3096-3110.

Santos-Sacchi J (1992) On the frequency limit and phase of outer hair cell motility: effects of the membrane filter. J Neurosci 12:1906-1916.

Satchell D (1990) The effects of ATP and related nucleotides on visceral smooth muscle. In: Biological actions of extracellular ATP (Dubyak GR, Fedan JS, eds), pp 53-63. New York: New York Academy of Sciences.

Scott TL (1985) Distances between the functional sites of the $\left(\mathrm{Ca}^{2+}\right.$
$+\mathrm{Mg}^{2+}$ )-ATPase of sacroplasmic reticulum. J Biol Chem 260:1442114423 .

Secrist JA, Barrio JR, Leonard NJ (1972) A fluorescent modification of adenosine triphosphate with activity in enzyme systems: $1, N^{6}-$ ethenoadenosine triphosphate. Science 175:646-647.

Sewell WF, Mroz EA (1993) Flavin adenine dinucleotide is a major endogenous fluorophore in the inner ear. Hearing Res 70:131-138.

Shigemoto T, Ohmori H (1990) Muscarinic agonists and ATP increase the intracellular $\mathrm{Ca}^{2+}$ concentration in chick cochlear cells. J Physiol (Lond) 420:127-148.

Silinsky EM, Gerzanich V, Vanner SM (1992) ATP mediates excitatory synaptic transmission in mammalian neurones. $\mathrm{Br} \mathrm{J}$ Pharmacol 106:762-763.

Soltoff SP, McMillian MK, Talamo BR, Cantley LC (1993) Blockade of ATP binding site of $P(2)$ purinoceptors in rat parotid acinar cells by isothiocyanate compounds. Biochem Pharmacol 45:1936-1940.

Thorne PR, Muñoz DJB, Housley GD, Billett TE (1993) Adenosine 5 -triphosphate (ATP) concentrations in the endolymph and perilymph of the guinea-pig cochlea. In: Biophysics of hair cell sensory systems (Duifhuis H, Horst JW, van Dijk P, van Netten SM, eds), p 412. Singapore: World Scientific.

Watanabe T, Inesi $G$ (1982) The use of 2',3'-O-(2,4,6-trinitrophenyl) adenosine 5 -triphosphate for studies of nucleotide interaction with sacroplasmic reticulum. J Biol Chem 257:11510-11516.

Westfall DP, Sedaa KO, Shinozuka K, Bjur RA, Buxton ILO (1990) ATP as a cotransmitter. In: Biological actions of extracellular ATP (Dubyak GR, Fedan JS, eds), pp 300-310. New York: New York Academy of Sciences.

Wills ED, Wormall A (1950) Studies on suramin. 9. The action of the drug on some enzymes. Biochem J 47:158-170.

Zimmermann H, Grondal EJM, Keller F (1986) Hydrolysis of ATP and formation of adenosine at the surface of cholinergic nerve endings. In: Cellular biology of ectoenzymes (Kreutzberg GW, Reddington M, Zimmermann H, eds), pp 35-48. Berlin: Springer. 